\title{
Biodiversity data requirements for systematic conservation planning in the Mediterranean Sea
}

\author{
Noam Levin ${ }^{1, *}$, Marta Coll $^{2,3}$, Simonetta Fraschetti ${ }^{4}$, Gideon Gal ${ }^{5}$, \\ Sylvaine Giakoumi ${ }^{6,7}$, Cordula Göke ${ }^{8}$, Johanna Jacomina Heymans ${ }^{9}$, \\ Stelios Katsanevakis ${ }^{10}$, Tessa Mazor $^{7}$, Bayram Öztürk ${ }^{11}$, Gil Rilov ${ }^{12}$, \\ Juliusz Gajewski ${ }^{13}$, Jeroen Steenbeek ${ }^{14}$, Salit Kark $^{7}$ \\ ${ }^{1}$ Department of Geography, The Hebrew University of Jerusalem Mt. Scopus, Jerusalem 91905, Israel \\ ${ }^{2}$ Institute of Marine Science (ICM-CSIC), Passeig Maritim de la Barceloneta, No. 37-49, 08003 Barcelona, Spain \\ ${ }^{3}$ Laboratoire Écosystèmes Marins Exploités, Institut de Recherche pour le Développement, UMR EME 212, Centre de Recherche \\ Halieutique Méditerranéenne et Tropicale, Avenue Jean Monnet, BP 171, 34203 Sète Cedex, France \\ ${ }^{4}$ Laboratory of Marine Biology, Università del Salento, DiSTeBA, CoNISMa, 73100 Lecce, Italy \\ ${ }^{5}$ Kinneret Limnological Laboratory, Israel Oceanographic and Limnological Research PO Box 447, Migdal 14950, Israel \\ ${ }^{6}$ Institute of Marine Biological Resources and Inland Waters, Hellenic Centre for Marine Research, Agios Kosmas, \\ 16777 Athens, Greece \\ ${ }^{7}$ ARC Centre of Excellence for Environmental Decisions, School of Biological Sciences, The University of Queensland, Brisbane, \\ Queensland 4072, Australia \\ ${ }^{8}$ Department of Bioscience, Aarhus University, Frederiksborgvej 399, PO Box 358, 4000 Roskilde, Denmark \\ ${ }^{9}$ Scottish Association for Marine Science, Scottish Marine Institute, Oban, Argyll PA37 1QA, UK \\ ${ }^{10}$ European Commission Joint Research Centre, Institute for Environment and Sustainability, Water Resources Unit, \\ Via E. Fermi 2749, Building 27, Ispra (VA) 21027, Italy \\ ${ }^{11}$ Laboratory of Marine Biology, Faculty of Fisheries, Istanbul University, Ordu Cad. No. 200, Laleli, Istanbul, Turkey \\ ${ }^{12}$ National Institute of Oceanography, Israel Oceanographic and Limnological Research (IOLR), PO Box 8030, Haifa 31080, Israel \\ ${ }^{13}$ Maritime Institute in Gdansk, ul. Dlugi Targ 41/42, 80-830 Gdansk, Poland \\ ${ }^{14}$ Ecopath International Initiative Research Association, Barcelona, Spain
}

\begin{abstract}
The Mediterranean Sea's biodiversity and ecosystems face many threats due to anthropogenic pressures. Some of these include human population growth, coastal urbanization, accelerated human activities, and climate change. To enhance the formation of a science-based system of marine protected areas in the Mediterranean Sea, data on the spatial distribution of ecological features (abiotic variables, species, communities, habitats, and ecosystems) is required to inform conservation scientists and planners. However, the spatial data required is often lacking. In this review, we aimed to address the status of our knowledge for 3 major types of spatial information: bathymetry, classification of marine habitats, and species distributions. To exemplify the data gaps and approaches to bridge them, we examined case studies that systematically prioritize conservation in the Mediterranean Sea. We found that at present the data required for conservation planning is generally more readily available and of better quality for the European countries located in the Western Mediterranean Sea. Additionally, the Mediterranean Sea is lagging behind other marine regions where rigorous criteria for conservation planning has been applied in the past $20 \mathrm{yr}$. Therefore, we call upon scientists, governments, and international governmental and non-governmental organizations to harmonize current approaches in marine mapping and to develop a framework that is applicable throughout the Mediterranean region. Such coordination between stakeholders is urgently needed before more countries undertake further extensive habitat mapping, so that future conservation planning can use integrated spatial datasets.
\end{abstract}

KEY WORDS: Conservation planning $\cdot$ Mediterranean Sea $\cdot$ Biodiversity $\cdot$ Habitats $\cdot$ Bathymetry Spatial data 


\section{INTRODUCTION}

\section{Marine environments and systematic conservation planning}

To effectively manage biological systems there is a need for good spatio-temporal knowledge of the area's landscape (or seascape), habitats, environmental conditions, and biota at the relevant scales. Much of our knowledge on how to manage ecosystems comes from the terrestrial environment; however, marine ecosystems are ecologically and environmentally different from terrestrial ecosystems (Carr et al. 2003). Key differences include the 3dimensional realm of the marine environment compared with the dominant 2-dimensional habitats of the terrestrial system, the extensive connectivity of metapopulations and communities due to the constant movement of the medium (water) they are immersed in, and the development of sessile animal life forms. The differences in environmental configurations and life forms as well as accessibility pose a challenge to marine conservation that is far greater than in the terrestrial realm.

Marine spatial planning, systematic conservation planning, and biodiversity management of marine resources require sound and verified knowledge of the distribution of biodiversity features (e.g. species, habitats) at the planning, legislation, and enforcement stages (Moilanen et al. 2009, Douvere 2010). While this knowledge is often quite advanced in the terrestrial environment, we are far from having sufficient knowledge for most species, communities, habitats, and ecosystems in the marine environment (Halpern et al. 2008). Contributions from species distribution models and other techniques are substantially advancing this knowledge at different geographic scales (e.g. Ben Rais Lasram et al. 2010, Kaschner et al. 2010, Jones et al. 2012), but major gaps still exist because sampling effort is highly patchy in both space and time.

The Mediterranean Sea is facing multiple human pressures (e.g. from population growth, tourism, shipping, fishing, and hydrocarbon extraction), and large-scale conservation planning is complicated by the large number of countries and their varying political and socioeconomic characteristics (Coll et al. 2010, 2012, Mouillot et al. 2011, Giakoumi et al. 2012a, Mazor et al. 2014). Although the cradle of western civilization is found around the Mediterranean Sea, and the coasts of this sea are among the most populated on earth, quantitative information about the geographical distribution of marine habi- tats and species is scant (Fraschetti et al. 2011, Coll et al. 2012, Micheli et al. 2013a). Furthermore, although this is a small and enclosed sea, many parts of it are deep and difficult to reach; the deepest point is the Calypso Deep in the Ionian Sea (5272 m; Costello et al. 2010a, Danovaro et al. 2010, see Fig. 1a).

There are a few possible reasons why conservation planning in the Mediterranean Sea seems to be lagging behind some other regions (see Turra et al. 2013), such as Australia or the USA, where systematic conservation planning principles have been applied to marine environments in the past $20 \mathrm{yr}$ (Leslie 2005). As the Mediterranean Sea is shared between many countries, coordination of conservation efforts is necessary. The important role of collaboration between countries in marine conservation has been recently emphasized in several papers, due to the economic gains it may provide (e.g. Mazor et al. 2013, 2014), and because between-country collaboration is necessary for creating trans-boundary protected areas (e.g. Levin et al. 2013).

One of the obstacles for planning in the marine environment is related to the variety of jurisdictions in the sea. There are various levels of marine sovereignty ranging from territorial waters (full sovereignty) to high seas (no national sovereignty) (Allott 1983, Chevalier 2005, Suárez de Vivero et al. 2009, 2010). These also affect the extent of mapping efforts, the sharing of information (e.g. bathymetric and biodiversity information, sometimes considered classified for security or commercial reasons), and thus the process of marine conservation planning.

\section{Bathymetric and biodiversity data}

Ideally, marine conservation planning should be based on detailed information of the distribution of all marine organisms in the study area. However, collecting such information is time consuming and economically unrealistic. Therefore, bathymetry and habitat distributions are often used as surrogates for species distribution in marine conservation planning (Ward et al. 1999, Johnson et al. 2013). Bathymetry is critical for conservation planning since it documents the changing morphology of the substrate (the topography and slopes). Furthermore, it can be used to create approximate species range distribution maps, as it correlates well with many crucial variables defining species distribution, such as light intensity, temperature, nutrient concentration, and primary and secondary productivity (Katsanevakis \& Maravelias 2009). 
Various technologies have been used to map bathymetry, some of which pre-date the 1950s, such as single-beam echo sounders (SBES) and side scan sonars (SSS), and some that rely on accurate positioning systems, such as multi-beam echo sounders (MBES), as well as LiDAR for mapping shallow water areas (Wozencraft \& Millar 2005, Anderson et al. 2008, Brown \& Blondel 2009, Pandian et al. 2009). In some cases, space-borne multispectral sensors may be used to retrieve water depth, but this is mostly limited to depths shallower than $25 \mathrm{~m}$ (Stumpf et al. 2003, Beaman 2010, Chust et al. 2010). Most seabed mapping techniques require a very large budget because of the unique technology required, the small area covered by one survey track, and the remoteness of marine areas due to the distance from the coastline and inhabited areas, and depth. As a result, bathymetric mapping is mainly performed according to the needs of large commercial operations (e.g. gas and oil companies), governments, and a small number of well-funded research organizations.

Collecting detailed biodiversity data and mapping spatial patterns of marine biodiversity across large spatial scales is challenging, and usually requires extensive and expensive sampling from vessels by nets, grabs, or corers, as well as sampling using scuba diving, which is limited to shallow waters. In marine environments, both visible and non-visible light is attenuated by seawater and is easily scattered when the water is turbid. Therefore, remotely sensed data, which is based on electromagnetic radiation, are only useful in very shallow areas $(<15$ to $20 \mathrm{~m}$ ) when and where the water is relatively clear (Chust et al. 2010, Dekker et al. 2011, Ma et al. 2014). Instead, sound waves that propagate through water are used to map the sea bottom (depth and type).

\section{Aims of this review}

The limited availability of biological data for most of the Mediterranean Sea (Coll et al. 2010, 2012, 2013, Fraschetti et al. 2011) hinders its spatial planning, management, and governance. Here, we aimed to assess the availability of spatial data for effective marine conservation planning. We posed several questions regarding the thematic and spatial resolutions of mapping and the extent to which spatial biodiversity and bathymetry datasets were used in several case studies of marine conservation planning. First, we reviewed representative examples of Mediterranean Sea datasets by documenting approaches used for mapping the 3 major components required and commonly used in marine conservation planning (and marine spatial planning in general): bathymetry, habitats, and species biodiversity. Second, we reviewed the marine conservation planning literature, aiming to scan current initiatives and advancements and examine the spatial resolution used in such plans. Specifically, we reviewed and examined the types of mapping information that are incorporated in conservation prioritization studies in the Mediterranean Sea (as done by Leslie [2005] at the global scale).

\section{FINDINGS}

\section{Bathymetric information}

Bathymetry is the most basic spatial information for habitat mapping in a marine environment. At a global scale, ETOPO2 and the General Bathymetric Chart of the Oceans (GEBCO) are examples of freely available (GEBCO only for scientific research and environmental conservation) and commonly used gridded bathymetry datasets (Marks \& Smith 2006). ETOPO2 data (available at www.ngdc.noaa.gov/ $\mathrm{mgg} / \mathrm{global} /$ etopo2.html) has a spatial resolution of 2 arc-minutes (equivalent to 2 nautical miles) and is built from numerous global and regional datasets (Amante \& Eakins 2009) (Fig. 1a). The current version (released in October 2010) of GEBCO is available as a 30 arc-second grid with the bathymetry and a grid documenting the sources (available at www. gebco.net/data_and_products/gridded_bathymetry_ data). It was generated by combining ship soundings, satellite-derived gravity data, and other methods (The GEBCO_08 Grid, version 2010927, www.gebco. net).

In December 2007, the European Parliament and Council adopted a common text for the Marine Strategy Framework Directive, which aims to achieve 'Good Environmental Status' by 2020 across Europe's marine environment (EC 2008). This directive included a requirement for an overarching European Marine Observation and Data Network (EMODnet). The EMODnet hydrography portal (http://portal. emodnet-hydrography.eu/\#) is currently being developed as part of the preparatory actions for the European Marine Observation and Data Network. It provides hydrographic data collated for a number of marine regions in Europe, including the Mediterranean (Fig. 1). These bathymetric databases incorporate data from a wide variety of sources (Fig. 2), collected using MBES, resampled to a coarse spatial resolution of 15 arc-seconds (Schaap \& Moussat 

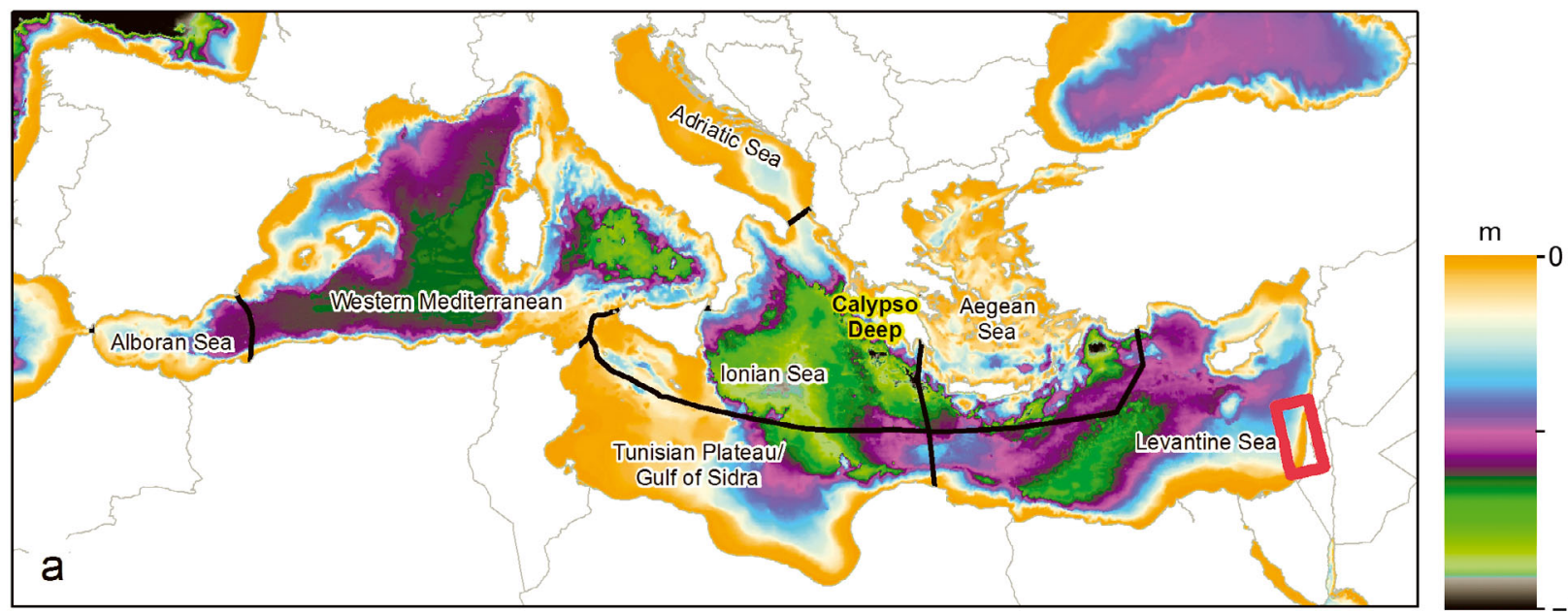

$0,100,200,4,4,400$ Nautical miles
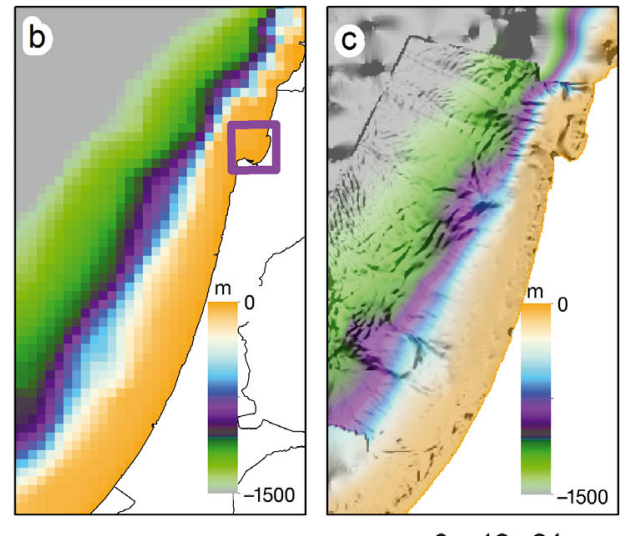

$\begin{array}{lll}0 & 12 & 24\end{array}$
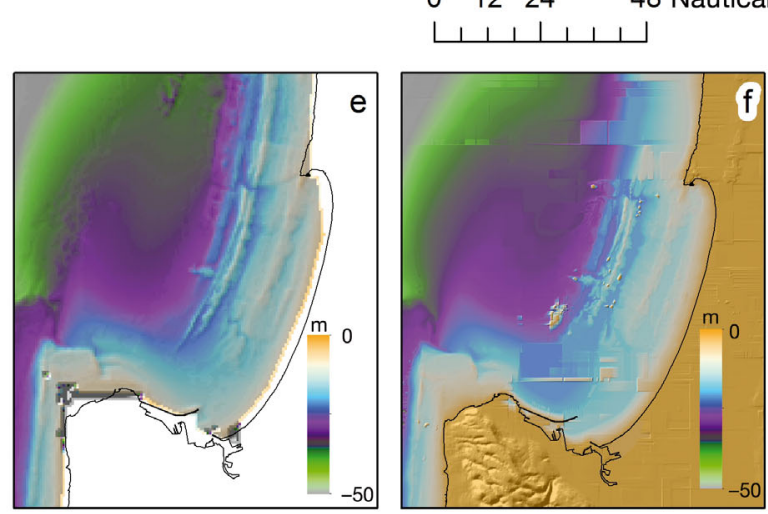

$\begin{array}{lll}0 & 1.5 & 3\end{array}$

6 Nautical miles

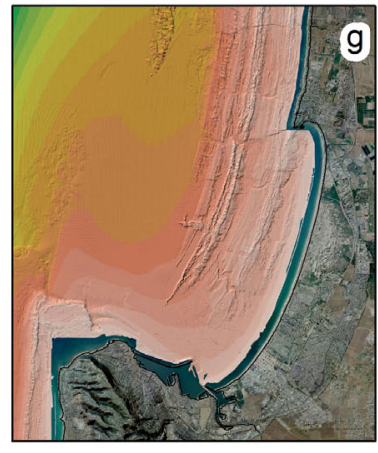

2013). According to the EMODnet website, as of mid2014 , the spatial resolution will be improved to 7.5 arcseconds. It should be noted that while the EMODnet (as well as other global bathymetric datasets) has a published spatial resolution, it comprises a variety of spatial sources that were resampled from finer- or coarser-resolution datasets to form a specific digital elevation model with a uniform spatial resolution
Fig. 1. Comparison of bathymetric datasets, focusing on the Eastern Mediterranean. (a) The global ETOPO2V2 digital elevation map (DEM) for the entire Mediterranean (depths colored between -4500 and $0 \mathrm{~m})$, with the names of the 7 marine ecoregions shown on top. The red rectangle is the area shown in panel b. (b) The ETOPO2V2 DEM zoomed in on the Eastern Mediterranean (depths colored between -1500 and $0 \mathrm{~m}$ ). The purple rectangle is the area shown in panel e. (c) The EMODnet dataset (depths colored between -1500 and $0 \mathrm{~m}$ ). (d) The Israeli multibeam dataset for the Eastern Mediterranean resampled to a spatial resolution of $100 \mathrm{~m}$ (depths colored between -1500 and $0 \mathrm{~m}$ ) with the spatial extent of the Israeli multibeam shown in yellow. (e) Israeli multibeam dataset zoomed in on the Bay of Haifa, Israel (depths colored between -50 and $0 \mathrm{~m}$ ). (f) The $25 \mathrm{~m}$ resolution Israel DEM of Hall (2008) for the Bay of Haifa (depths colored between -50 and $0 \mathrm{~m}$ ). (g) A highspatial-resolution image of the bathymetry of the Bay of Haifa, cre ated by Sade et al. (2006b)
(Costello et al. 2010a). The actual accuracy of the field data used to create a bathymetric map should be considered by users (using maps as in Fig. 2) - they cannot assume that the published map resolution reflects the accuracy of that map.

While EMODnet provides higher-spatial-resolution digital bathymetry for the entire Mediterranean (compared with global datasets), its spatial resolution 

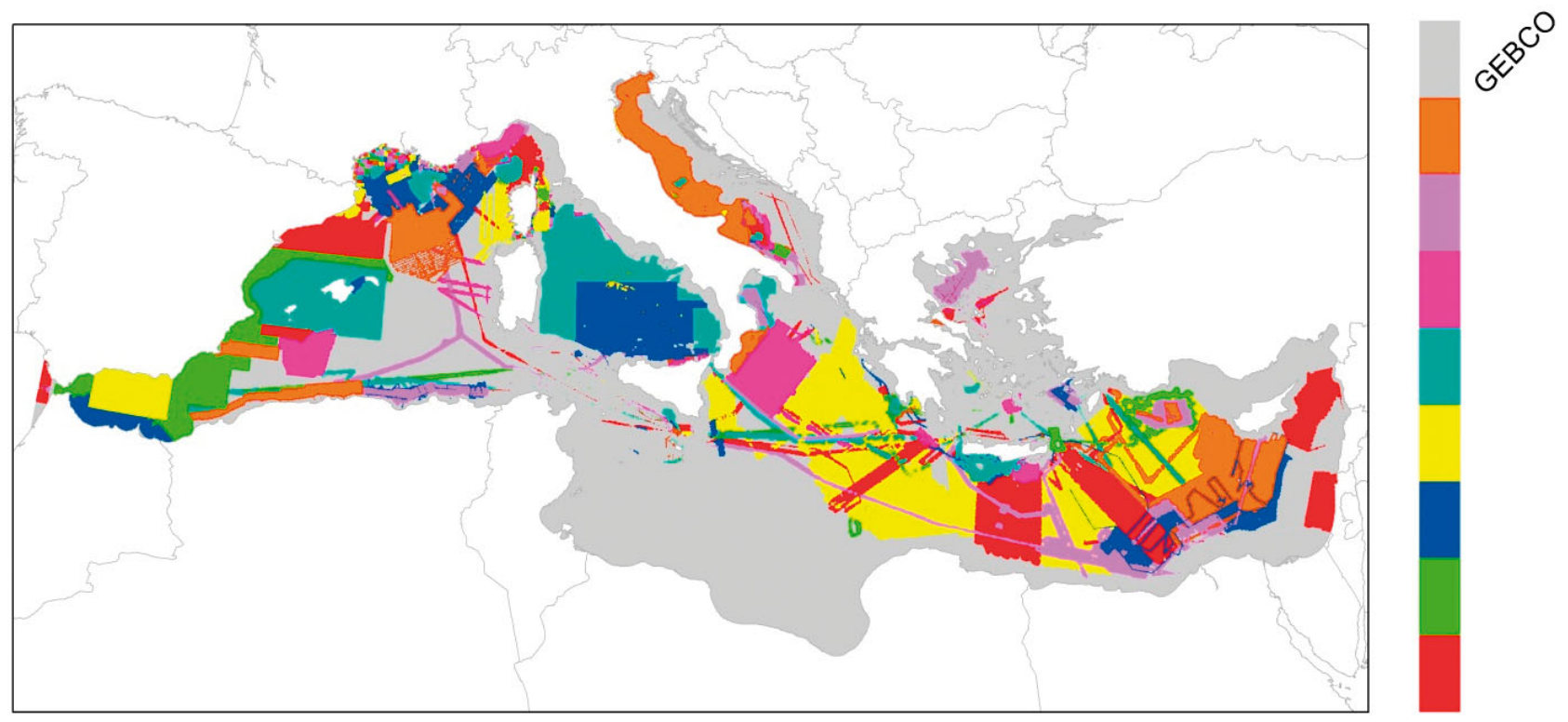

EMODnet bathymetry origin

Fig. 2. Source reference for the EMODnet bathymetric data (as shown in July 2013 at http://portal.emodnet-hydrography. eu/\#). Colors show areas with the same bathymetry origin (GEBCO being a globally available, coarse-resolution bathymetric dataset). The colors have no other goal than to distinguish areas that have different data sources, as shown on the EMODnet website

is only about $450 \mathrm{~m}$. For about half of the Mediterranean Sea, bathymetry is derived from GEBCO (1 arcminute version interpolated from $500 \mathrm{~m}$ interval contours digitized from paper charts at 1:10 million scale; Marks \& Smith 2006; Fig. 2), thus reducing its effectiveness for use in many applications (Fisher \& Tate 2006). An integrated version combining EMODnet with GEBCO across the whole basin is not available yet, even though there is an ongoing effort to combine the 2 datasets. Better datasets are commonly available at national scales, depending on the aims of the bathymetric surveys conducted in each country. In Israel, for example, up until the 1990s there were very few bathymetric surveys conducted by the state. Israel's first national digital elevation model was prepared by John Hall at a spatial resolution of $25 \mathrm{~m}$ more than 20 yr ago (Hall 2008), covering only a small part of Israel's Mediterranean waters (Fig. 1f). New multi-beam surveys have been conducted over the last decade, covering about half of Israel's potential exclusive economic zone, to a distance of about 30 nautical miles from the shore (Sade et al. 2006a, b; Fig. $1 \mathrm{~d}$ and the red rectangular area the southeastern Mediterranean shown in Fig. 2). These surveys provide high-spatial-resolution data; however, they are not available for the general scientific community at full resolution (for national security reasons), and were only made available to us at a downgraded resampled resolution of ca. $100 \mathrm{~m}$. While the bathymetry at a spatial resolution of $100 \mathrm{~m}$ is indeed better than that freely available from EMODnet, showing the main undersea longitudinal north-south aeolionite ridges (submerged palaeo-dunes), fine-spatialresolution features captured by the multi-beam surveys are lost (compare Fig. 1e and $1 \mathrm{~g}$ ). As habitat mapping always requires detailed bathymetric information (to identify small ridges, rivers, and cliffs on the sea bottom), there seems to be a conflict between national security requirements and conservation planning needs.

\section{Habitat classification and mapping}

The division of the Mediterranean Sea into classified marine ecoregions (e.g. by Spalding et al. 2007; Fig. 1a), although helpful for guiding equitable representation of the area (Giakoumi et al. 2013), is not intended to (and cannot) define marine habitats. There are multiple schemes aimed towards defining marine habitats in Europe (see review by Fraschetti et al. 2008). These include Natura 2000, EUNIS (European Nature Information System), OSPAR (named after the Oslo and Paris conventions; OSPAR 2003), and the MSFD (Marine Strategy Framework Directive) (see Table S1 in the Supplement at www. 
int-res.com/articles/suppl/m508p261_supp.pdf for a more comprehensive list). In addition to these collaborative efforts, standard labels can be found on nautical charts, which are used to portray the type and nature of the seabed (e.g. fine sand; see more examples in Table S1).

The Natura 2000 sites (www.eea.europa.eu/dataand-maps/data/natura-2) are a network of protected areas set up to ensure the conservation of Europe's most valuable species and habitats. Currently (after some amendments in 2006), the Habitats Directive Annex I (of Natura 2000) contains 218 habitats of conservation importance, and Annex II contains 887 species. In total, only $9(4.1 \%)$ of the 218 habitats described in Natura 2000 are marine or coastal. However, there are no maps providing the complete spatial distribution of all or most of these habitats across the entire Mediterranean basin (Giakoumi et al. 2013, Martin et al. 2014). In the Mediterranean Sea, the Natura 2000 sites have been generally established because of the presence of the seagrass Posidonia oceanica.

EUNIS is the European Nature Information System (http://eunis.eea.europa.eu) developed between 1996 and 2001 by the European Environment Agency. It classifies pan-European habitats hierarchically, and covers natural, artificial, aquatic, and terrestrial habitats. It has 4 large classifications of marine and coastal habitats, namely: (1) marine habitats (code A); (2) coastal habitats (code B); (3) constructed, industrial, and other artificial habitats (including sea walls, etc.; code J); and (4) habitat complexes (including estuaries, etc.; code X). At the second level of hierarchy, out of a total of 86 classes, 11 EUNIS classes are either marine or coastal. Within these EUNIS classes, 5282 habitats have been defined, of which 1098 are marine and 178 are coastal; thus, $24.1 \%$ are either marine or coastal (see also Salomidi et al. 2012). Within the EUSeaMap project (http://jncc.defra.gov.uk/page-5020), the Western Mediterranean (as well as the Baltic Sea, the North Sea, and some of the NE Atlantic) was mapped based on existing data and GIS layers representing both seabed habitats and seabed substrata that are freely available for download (Fig. 3). In total, the seabed habitats layer in the Western Mediterranean includes 31 EUNIS habitats (belonging to 4 EUNIS level 2 marine classes), mapped at a spatial resolution of $0.0027^{\circ}$ (about $200 \mathrm{~m}$ ), while there are only 8 classes of seabed substrata mapped (Fig. 3). These EUNIS layers are much more detailed in the shallow areas near the coast (Fig. 3c,d). A significant correlation was found between the depth and the number of
EUNIS seabed habitat classes within an area of $4 \mathrm{~km}^{2}$, with more detailed information in shallower areas $(\mathrm{r}=0.55, \mathrm{p}<0.001$; a similar pattern was found between depth and biodiversity observations, see Duffy et al. 2013). While both EUSeaMap layers seem quite detailed, when zooming in the differences between them are obvious, with the EUNIS seabed habitats map being more coarse due to the spatial resolution used $(200 \mathrm{~m})$. When compared with a local 1:25000 map of marine bottoms from the marine protected area of Tavolara Capo Coda Cavallo (NE Sardinia, Italy) (Fig. 3e; map available online from Seascape Evaluation Assessment and Mapping at www. seamap.it/?page_id=876 - accessed 10 May 2013), the necessary simplification used in the EUSeaMap database clearly shows the limitation to the targeted overview scale of the data (Rovere et al. 2013). Thus, the choice of the appropriate dataset of marine habitats to use should also depend on the scale of the dataset and the extent of the planning study area.

Undertaking marine conservation planning in an area that is covered by several data sources with different classification approaches can be problematic (Dauvin et al. 2008a) since it is essential to have data that are comparable both thematically (class definitions) and in scale. With the availability of new technologies, seabed mapping efforts are increasing. Coggan et al. (2007) reviewed the existing standards for surveying operation procedures, from which the Recommended Operating Guidelines were derived. These guidelines focus on habitat mapping down to a depth of $200 \mathrm{~m}$ and groundtruthing. Besides groundtruthing as a standard to verify the mapped data, the framework for Mapping European Seabed Habitats (MESH; which ran between 2004 and 2008) also suggested providing confidence maps and metadata with the data (Foster-Smith et al. 2007).

Another classification of predominant marine habitats across all regions and subregions of Europe is included in a European Commission staff working document (EU 2011). This document aims to facilitate the consistency of assessments and the comparability of monitoring results for the MSFD. This classification is directly linked to the EUNIS habitat classification scheme. It treats habitats together with their associated biological features, and includes 5 water column habitats (combined with phytoplankton and zooplankton communities) and 18 seabed habitats (combined with angiosperms, macroalgae, invertebrate bottom fauna, and associated vertebrate fauna). Member states were asked in 2012 to conduct all required MSFD reporting accordingly (EC 2012). 


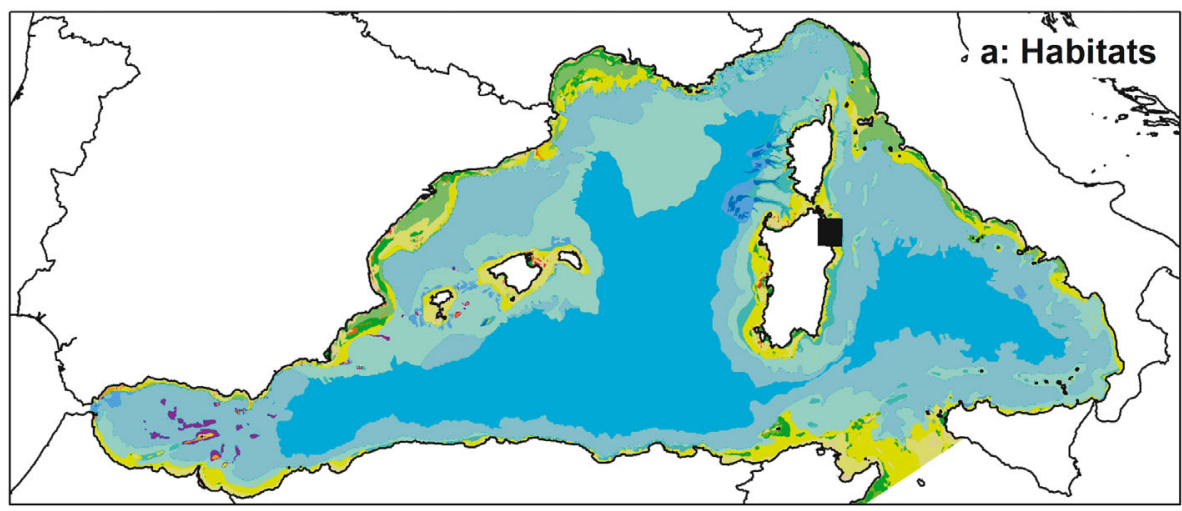

\section{EUSeaMap - Modelled Seabed Habitats}

A3: Infralittoral rock and other hard substrata

A4.26: Mediterranean

coralligenous communities

moderately exposed to

hydrodynamic action

A4.27: Faunal communities on

deep moderate energy circalittoral

rock

A5.13: Infralittoral coarse sediment

A5.23: Infralittoral fine sands

A5.33: Infralittoral sandy mud

A5.34: Infralittoral fine mud

A5.38: Mediterranean biocoenosis of muddy detritic bottoms

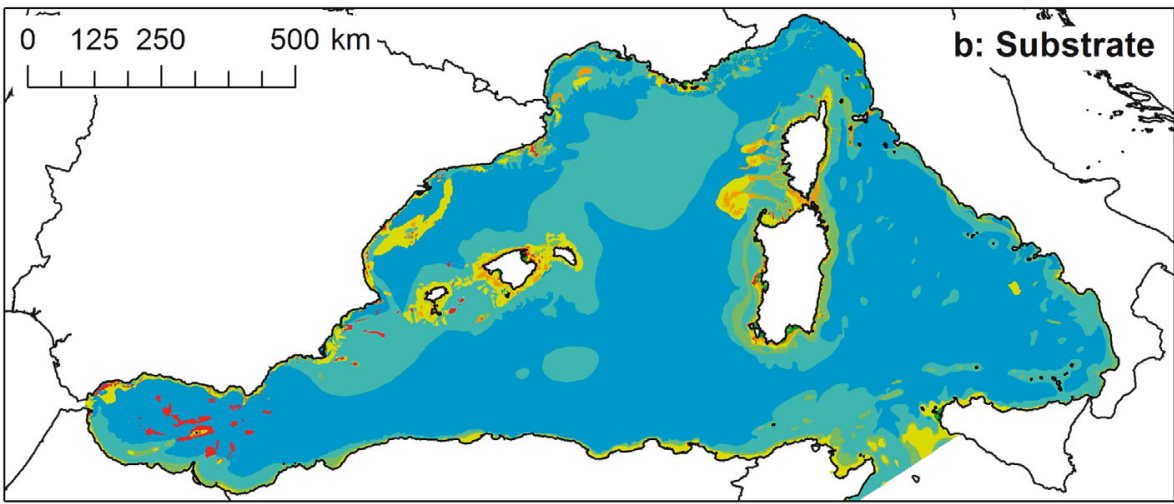

A5.39: Mediterranean biocoenosis of coastal terrigenous muds

A5.46: Mediterranean biocoenosis of coastal detritic bottoms

A5.47: Mediterranean communities

of shelf-edge detritic bottoms

A5.531: [Cymodocea] beds A5.535: [Posidonia] beds

A6.1: Deep-sea rock and artificial hard substrate

A6.2: Deep-sea mixed substrate

A6.3: Deep-sea sand

A6.4: Deep-sea muddy sand

A6.511: Facies of sandy muds with Thenea muricata

A6.51: Mediterranean communities of bathyal muds
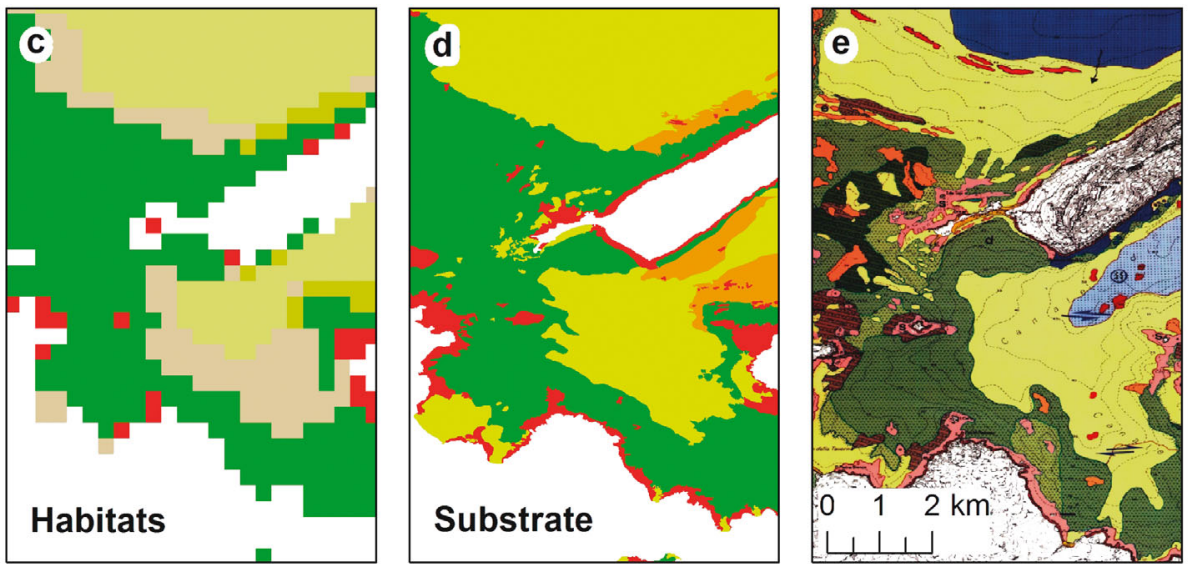

A6.52: Communities of abyssal muds

\section{EUSeaMap - substrate}

\begin{tabular}{|l|}
\hline Rock \\
Coarse and mixed \\
sediment \\
\hline Mud \\
\hline Sandy mud \\
\hline Muddy sand \\
\hline Sand \\
\hline Posidonia oceanica \\
Cymodocea nodosa \\
\hline
\end{tabular}

Fig. 3. EUNIS modeled (a) seabed habitats and (b) seabed substrate for the Western Mediterranean. (c,d) A close-up of these layers, respectively, compared with (e) a finer-detailed 1:25000 map of marine bottoms from the marine protected area of Tavolara Capo Coda Cavallo (NE Sardinia, Italy; black box in panel a). Sources: EUNIS data: http://jncc.defra.gov.uk/page5020; Tavolara map: www.seamap.it/?page_id=876

Given the wide heterogeneity of habitat classification schemes, Fraschetti et al. (2008) proposed a list of 94 Mediterranean marine habitat types. That work attempted to provide a simple and flexible tool for the evaluation of biodiversity at the habitat level, aiming to lead to more feasible conservation measures. Habitat mapping is commonly used as surrogate for patterns of biodiversity; however, in a study conducted in Moreton Bay (Australia), it was found that abiotic variables that have been correlated with biological distributions only explain a small proportion of the overall distribution $(<30 \%$; Stevens \& Connolly 2004, but see Ward et al. 1999). This may be due to the fact that much of the variability in distribution may be dependent on species interactions that occur at small scales but are translated to larger-scale patterns, and also due to seasonality (that is, the same habitat can host different communities in different seasons). 


\section{Species distribution data}

Within systematic conservation planning, it is important to explicitly incorporate information about species distribution and to set quantitative conservation targets for each species (e.g. the area required for the persistence of a species). For marine conservation planning to be effective at protecting all marine biodiversity in a given area, focusing only on marine habitats' definition should not be the sole criteria, and mapping biodiversity at the species level is needed. As it is impossible to map all species due to resource limitations, surrogate species (e.g. vulnerable, flagship, and umbrella species) are often used for prioritizing conservation areas and management of marine environments (Zacharias \& Roff 2001). However, the utility of flagship and umbrella species as surrogates for regional biodiversity was found to be limited since using a single taxon as a predictor of overall species richness can be problematic and its use in conservation planning may be inappropriate (Andelman \& Fagan 2000).

The state of knowledge of marine biota at the taxonomic level (i.e. regional species lists) is relatively high for the Mediterranean in most regions and for most eukaryotic groups compared with most seas (Coll et al. 2010). However, deep-sea areas remain largely unexplored as research efforts have been concentrated in coastal environments (Costello et al. 2010b). Some standardized approaches and protocols do exist for mapping pelagic and benthic marine populations. These include the International Bottom Trawl Survey in the Mediterranean (MEDITS, Bertrand et al. 2002), initiated in 1994, and the Mediterranean Acoustic Surveys (MEDIAS, MEDIAS 2010), that started in 2008, targeting small pelagic fish. These international surveys, although not covering the entire basin but mainly EU countries, provide standardized common approaches to survey demersal and small pelagic species diversity. Such information is valuable for fisheries management and mapping species biodiversity (although the information on invertebrate species and plants is less abundant than for fish species). The common protocols include standards for the survey design, the sampling gear, the information collected, and the management of the data (Bertrand et al. 2002, MEDIAS 2010). However, some organizations are not as willing to share information and thus these ecological data are often unavailable to end users, the scientific community, and broad-scale conservation planning (Coll et al. 2013). Another example of the unavailability of data can be taken from a new EU council regulation, pro- tecting the confidentiality rights of individual fishers, and thus making access to high-resolution fishing effort data unavailable to the scientific community (Hinz et al. 2013).

The United Nations Food and Agriculture Organization (FAO) provides a recommended protocol for the execution of acoustic surveys for deep-sea species by fishing vessels (FAO 2012). The recommendations address issues such as the acoustic equipment to be used, processing of data, survey methods, the estimation of biomass abundance and the associated uncertainties, and supplementary biological data required for interpretation of acoustic information.

Advances in remote-sensing technologies have enabled better monitoring and data of the physical state of the oceans globally (for sea surface temperature, chlorophyll concentrations, wave heights, and oil spills, to name just a few variables; Mumby et al. 2004). In comparison, detailed spatial information on the distribution of species is limited because of surveying challenges and spatio-temporal dynamics. As a result, there are now calls for a Marine Biodiversity Observation Network (Duffy et al. 2013). EurOBIS the European node of the international Ocean Biogeographic Information System (OBIS) - is an integrated data system developed by the Flanders Marine Institute (VLIZ). EurOBIS publishes distribution data on marine species collected within European marine waters as well as collected by researchers outside European marine waters, freely available online at www.eurobis.org (Vandepitte et al. 2011). EurOBIS was used as the data engine for the biological component of the EMODNet system, forming the new EMODNet Biology, with the aim of making available the data from the national marine monitoring campaigns of the different EU countries (Simon et al. 2013). These datasets can be searched and downloaded from www.emodnet-biology.eu/ portal/.

Spatial biodiversity datasets can be searched and downloaded from www.iobis.org/mapper (Ocean Biogeographic Information System). We downloaded 142 available datasets for the Mediterranean Sea from the OBIS website (accessed 13 February 2014), totaling 448563 records (27368 of these records from the MedOBIS dataset, described below). From mapping these records at a spatial resolution of $0.025^{\circ}$ (ca. 2.5 km; Fig. 4), it becomes evident that sampling effort is not distributed equally in the Mediterranean Sea. Spatial data is relatively abundant for Spain and France, whereas for other countries (e.g. Libya, Egypt, and Syria) data is scarce. 
The IUCN (2012) provides global digital species range maps of the IUCN Red List of Threatened Species for marine fish (1142 species), sea grasses (72 species), and corals as well as for terrestrial taxa. Similar to the habitat data, these species range maps are very coarse, or even show the spatial range of marine species simply as buffer zones of ca. $100 \mathrm{~km}$ from the coast (as in the example shown in Fig. 5d). Distributed as vector polygons of species ranges, such layers may seem to be accurate (as there are clearly defined lines in vector layers), and their coarse resolution is not apparent. As an illustration to the problematic nature of using global layers for a regional analysis, the IUCN species range map of the seagrass $P$. oceanica, endemic to the Mediterranean Sea, demonstrates a uniform presence of this seagrass within a very wide and unrealistic coastal buffer zone (see p. 16 in Pergent et al. 2012), including areas from which it is reported and modeled to be absent (compare with $P$. oceanica mapping performed in the MEDISEH [Mediterranean sensitive habitats] MAREA project http://mareaproject.net/ contracts/5/overview/, Giannoulaki et al. 2013; and in the NETMED project, Giakoumi et al. 2013). Users of such data should be aware that most species are not evenly distributed within their ranges.

An example of an initiative aimed at collating spatial datasets, specifically for alien species, is the European Alien Species Information Network (EASIN; Katsanevakis et al. 2012). This network pro- vides a platform through which spatial information from many data providers is integrated and distribution maps of single species or species aggregations can be produced (Fig. 6). Such efforts for the integration of available information can improve our knowledge of the distribution of species. However, due to the large variation among Mediterranean countries in monitoring effort (Katsanevakis et al. 2013), there is still a substantial bias in mapping species biodiversity, which limits Mediterranean-wide efforts for conservation prioritization. In addition, a monitoring and reporting bias favoring coastal areas exists. For example, very few alien species have been reported in offshore areas (Fig. 6), which may be explained by the thriving of shallow-water thermophilic demersal aliens introduced through the Suez Canal, as important vectors of alien species (ships and aquaculture) operate in shallow waters (Katsanevakis et al. 2013), but also due to the reduced sampling effort offshore (Danovaro et al. 2010).

\section{Species distribution modeling}

Modeling is another approach for filling the data gaps we have on species distribution. Models are usually based on physical and environmental variables (e.g. water temperature, salinity, depth, nutrient concentrations, seabed types), which are typically cheaper to record and map across vast

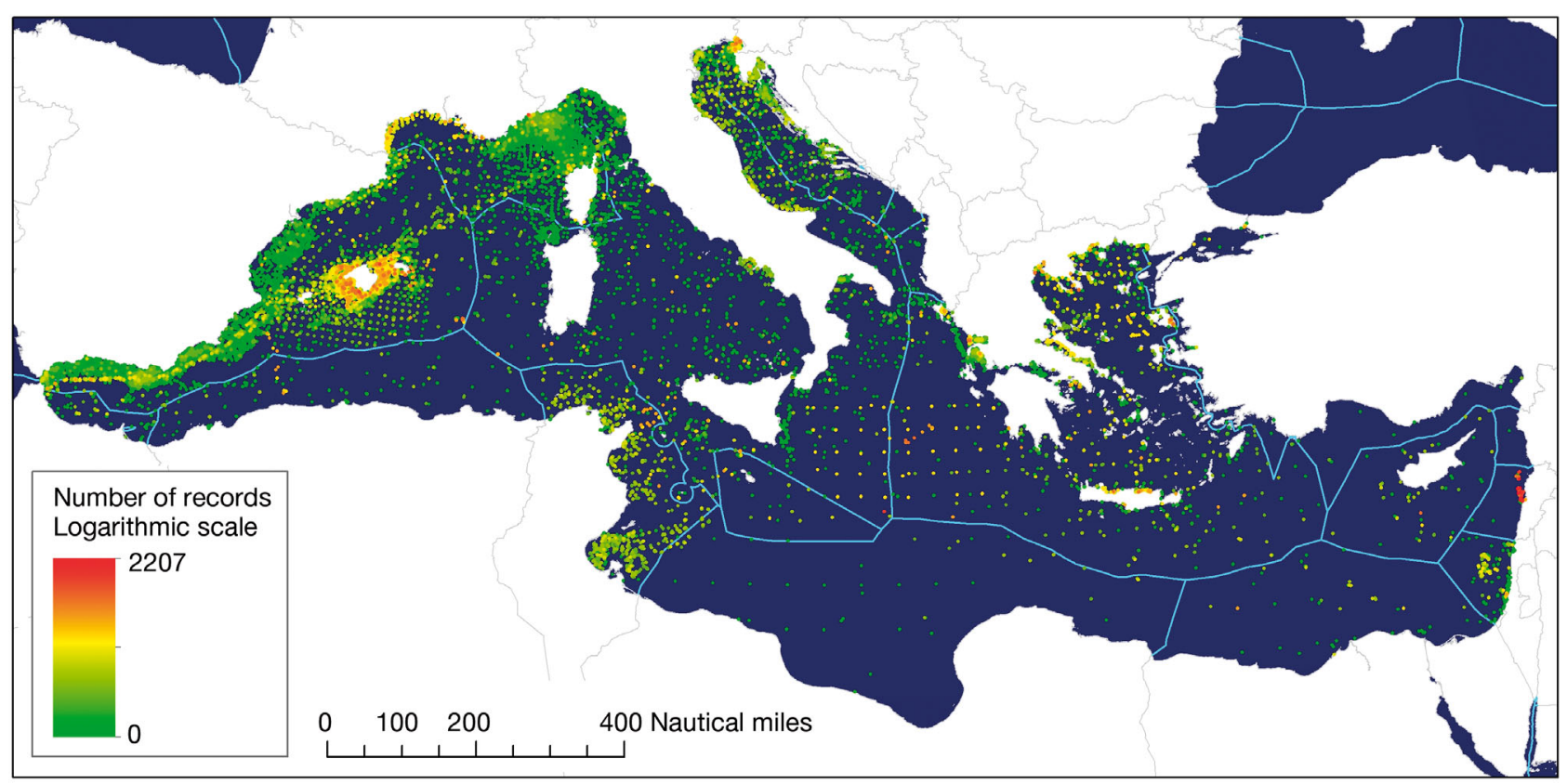

Fig. 4. Number of data records available for the Mediterranean Sea based on the Ocean Biogeographic Information System. Source: www.iobis.org/mapper 

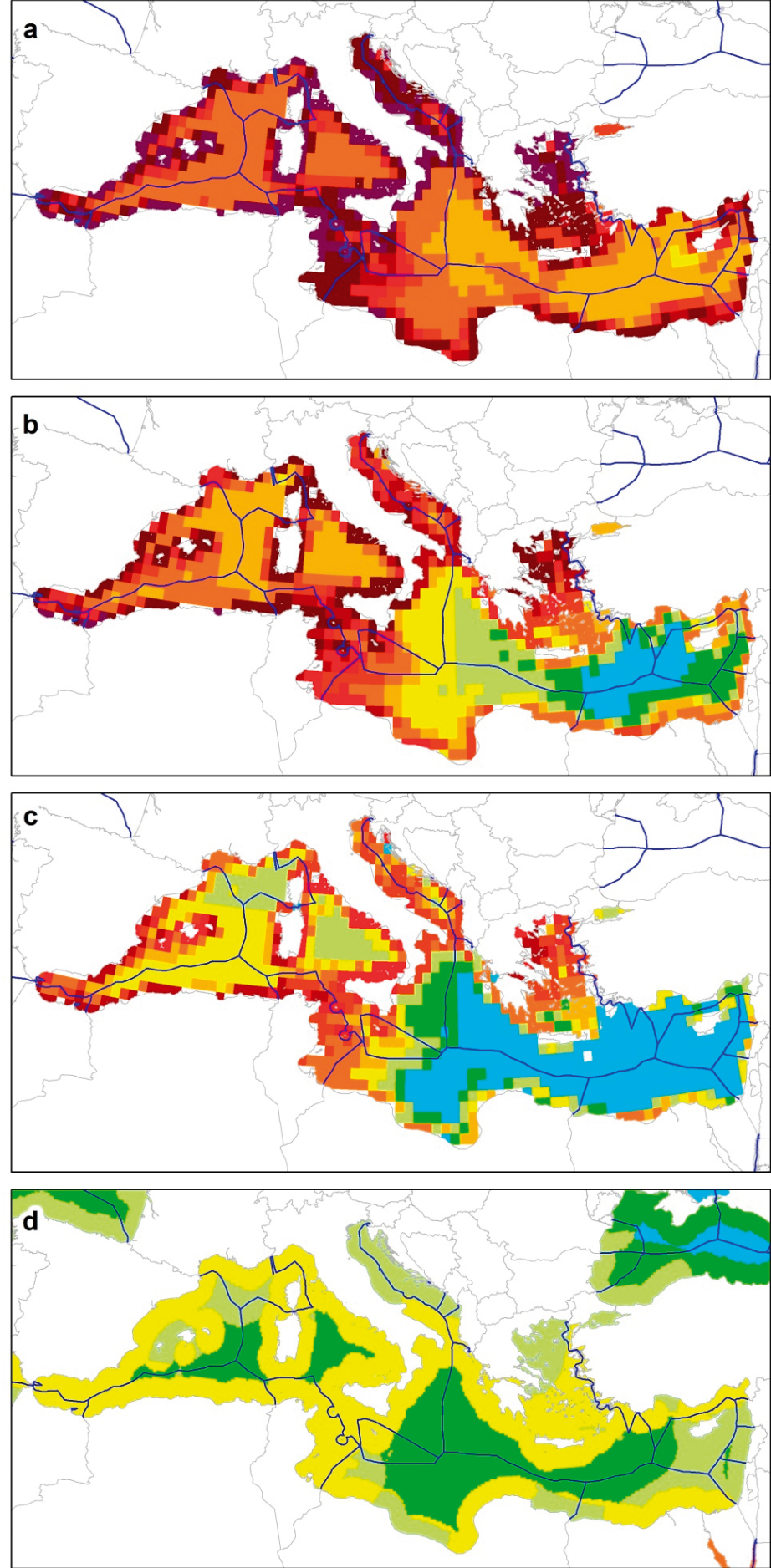

\begin{tabular}{|c|c|c|}
\hline$\geq 751$ & 201-300 & $11-25$ \\
\hline $501-750$ & $101-200$ & $6-10$ \\
\hline $401-500$ & $51-100$ & $1-5$ \\
\hline $301-400$ & $26-50$ & 0 \\
\hline
\end{tabular}

Fig. 5. Marine species richness maps of the Mediterranean Sea based on AquaMaps data for different probabilities of species occurrences: (a) $>0 \%$; (b) $>50 \%$; (c) $100 \%$. Source: http://aquamaps.org/. (d) Marine fish species richness based on IUCN species range data. Source: www.iucnredlist.org/technical-documents/spatial-data expanses, in contrast to species and habitat data. Those are known as bioclimatic envelope models. Newer, more advanced models also incorporate life history, species traits, physiological tolerances, population dynamics, and species interactions, and are known as dynamic bioclimatic envelope models. The use of either type of model is still very limited at the entire Mediterranean Sea scale. Examples for regional modeling of key marine species in the Mediterranean include those of Morfin et al. (2012) for key exploited marine species in the Northwestern Mediterranean Sea, and Fouzai et al. (2012) in the Northern-Central Adriatic Sea. Based on temporal dynamics, such models provide annual or monthly probability or density maps for each species, using bioclimatic envelope models and remotely sensed data of sea surface temperature, chlorophyll concentrations, salinity, wave energy, etc. (Cheung et al. 2009) or food web models including prey-predator dynamics (Christensen \& Walters 2011). Recently Martin et al. (2014) developed a predictive model, based on environmental predictors, to produce the first continuous, high-resolution maps of coralligenous outcrops and maërl beds across the entire basin. These predicted occurrence maps for the 2 habitats provide critical information about where the 2 habitats are most likely to occur. Two species for which detailed modeling of potential habitat has been conducted are the Atlantic bluefin tuna (feeding and spawning habitats in the entire Mediterranean Sea; Druon et al. 2011) and the fin whale (potential feeding habitat in the Western Mediterranean; Druon et al. 2012). Initiatives to bridge species distribution models and food web models are currently being developed (Steenbeek et al. 2013, Albouy et al. 2014).

Examples of global, linked, and freely available information systems that can be used for marine conservation planning are Fishbase (www.fishbase.org), OBIS (www. iobis.org) and AquaMaps (http://aquamaps. org). In conjunction, these databases provide a wealth of spatial, quantitative, and qualitative information about most of the known fish species, such as probabilities of occurrences for the native range of marine species, their suitable habitat (based on distance from land, 


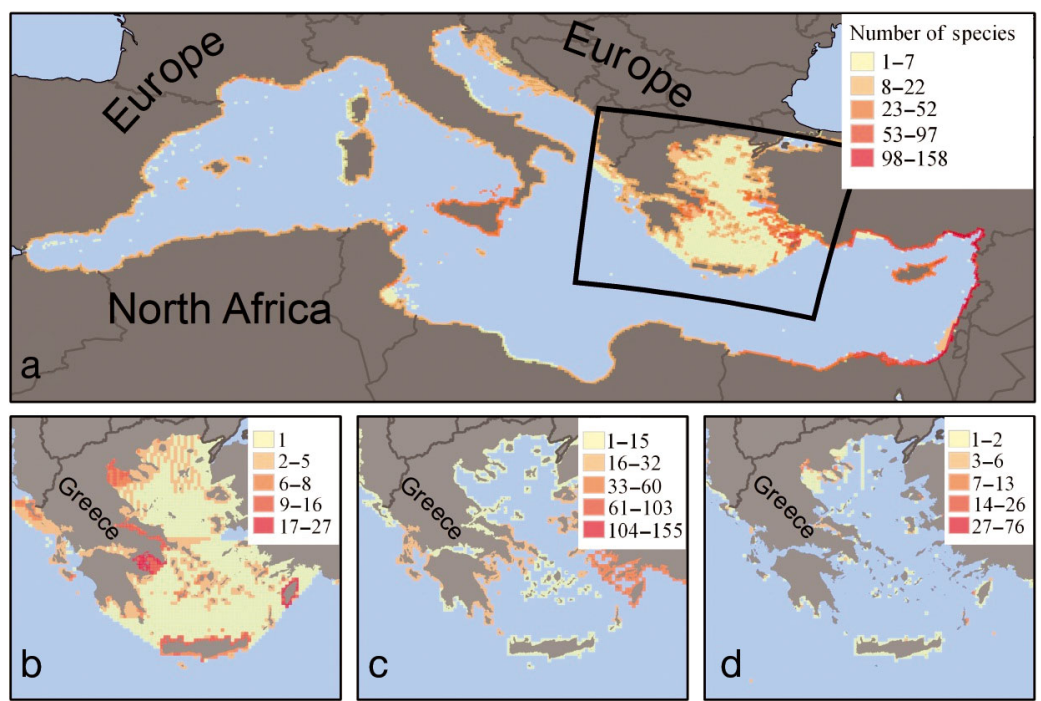

Fig. 6. (a) Distribution map of marine alien species (colors show number of species) in the Mediterranean Sea, produced using the mapping tools of EASIN (European Alien Species Information Network, http://easin.jrc.ec. europa.eu/) and integrating spatial information from CIESM (the Mediterranean Science Commission, www.ciesm.org/online/atlas/index.htm), ELNAIS (Ellenic Network On Aquatic Invasive Species, https://services.ath.hcmr.gr/), GBIF (Global Biodiversity Information Facility, www.gbif.org), GISIN (Global Invasive Species Information Network, www.gisin.org), REABIC (Regional Euro-Asian Biological Invasions Centre, www.reabic.net/GIS_europe.html), and EASIN-Lit (http://easin.jrc.ec.europa.eu/About/EASIN-Lit). In a close-up of the Greek Seas, different patterns are found if only (b) ELNAIS, (c) CIESM, or (d) EASIN-Lit and GBIF data are used, which demonstrates that inference of spatial patterns is greatly dependent on the data provider them: (1) species richness is higher near land; (2) a northwest to southeast gradient is apparent following a productivity gradient (Bosc et al. 2004, Tecchio et al. 2010); and (3) our knowledge about species distribution in the Eastern Mediterranean is lacking compared with the Western Mediterranean (Coll et al. 2010). This has been confirmed using cumulative species distribution data mostly available in the form of expert-drawn maps or sighting locations of invertebrate and vertebrate species (Ben Rais Lasram et al. 2009, Coll et al. 2010, 2012).

\section{Spatial resolution applied in marine conservation planning}

The spatial resolution applied in systematic conservation planning clearly has an effect on its outcomes. When aiming to prioritize areas for conservation, there is a need to define the number and spatial configuration of the planning units, which depends on the spatial scale of the decisionmaking process, the spatial extent of the study area, and spatial resolution depth, temperature, primary productivity, salinity, and sea-ice), and projections (Froese \& Pauly 2013). FishBase is linked with many other global initiatives in Biodiversity Informatics either by extracting data, such as from the Global Biodiversity Information Facility (GBIF) and OBIS for occurrences, and the IUCN Red List for threat status, or by providing information to the Catalogue of Life, GenBank, FishBoL (Barcode of Life), Encyclopedia of Life, and IUCN, among others. AquaMaps, for example, currently provides standardized range maps for 11500 species of fishes, marine mammals, and invertebrates (Kaschner et al. 2010). Within the Mediterranean Sea, species range maps are available via AquaMaps for about 856 native marine species (117 of them expert reviewed, as of July 2013) (Coll et al. 2010). We calculated marine species richness in the Mediterranean using data from AquaMaps and derived 3 richness maps, for species with probability (as modeled by AquaMaps) $>0 \%,>50 \%$ and with probability of $100 \%$ in a $0.5^{\circ}$ grid cell resolution (Fig. 5a-c). Three patterns emerged from these maps regarding the spatial distribution of marine species and our knowledge about at which biodiversity data is available (Ardron et al. 2008). Priority setting for systematic conservation planning involves the definition of quantitative goals for conserving biodiversity features (e.g. area required for ensuring the persistence of a specific species or habitat), and the identification of priority areas that succeed in maximizing the achievement of conservation goals while minimizing threats or costs (Margules et al. 2002). In a synthesis of marine conservation planning approaches done by Leslie (2005), 27 marine conservation planning cases from around the world were compared. The planning region size in these 27 cases ranged between $2435 \mathrm{~km}^{2}$ and 361 million $\mathrm{km}^{2}$ (the entire oceans) (median of $284300 \mathrm{~km}^{2}$ ), the planning unit size ranged between 0.3 and 1.0 million $\mathrm{km}^{2}$ (median of $739 \mathrm{~km}^{2}$ ), and the relative area of the planning unit size with respect to the total study area ranged between 0.0003 and $6 \%$ (median of $0.3 \%$ ). Interestingly, none of the cases reviewed by Leslie (2005) concerned the Mediterranean Sea, although there have been some examples of designing marine protected areas in the Mediterranean using multiple criteria analysis (as in Villa et al. 
2002). It should be noted, however, that in recent years, there has been a rapid increase of studies aimed at understanding biodiversity patterns, identifying biodiversity hotspots, and selecting priority conservation areas at a whole Mediterranean Sea scale (e.g. Coll et al. 2010, 2012, Giakoumi et al. 2013, Micheli et al. 2013a).

Since the early 2000s, at least 9 studies have applied systematic conservation planning principles to the Mediterranean Sea. These studies defined quantitative goals for the conservation of biodiversity features (Table 1). Five of these studies covered the entire Mediterranean Sea; in 4 studies, a square planning unit of $100 \mathrm{~km}^{2}$ was employed (Giakoumi et al. 2013, Levin et al. 2013, Mazor et al. 2013, 2014), whereas in Giannoulaki et al. (2013), hexagonal planning units were used (side of the hexagon: $20 \mathrm{~km}$; total area of each hexagon: $1039 \mathrm{~km}^{2}$ ). The 4 remaining systematic conservation planning studies examined local areas (planning unit size ranging between 0.01 and $400 \mathrm{~km}^{2}$ ) in Greece (Giakoumi et al. 2011, 2012b) and in Italy (Fraschetti et al. 2009: planning unit size $0.01 \mathrm{~km}^{2}, 1: 10000$ scale map, bathymetric map available; Maiorano et al. 2009, planning unit size $400 \mathrm{~km}^{2}$ ). In 3 of the 5 Mediterranean-wide studies, biodiversity target features were based on IUCN species-wide distribution layers, tackling between-country collaboration issues in conservation, whereas Giakoumi et al. (2013) and Giannoulaki et al. (2013) mapped key Mediterranean habitats as their biodiversity targets. In the local case studies, field surveys, including both habitat and species information, were often used. The relative size of the planning units to the total study area in these 7 studies ranged between 0.004 and $1.2 \%$ (i.e. around the median of $0.3 \%$ reported by Leslie [2005]). These Mediterranean examples demonstrate the wide range of applications for which systematic conservation planning can be applied (ranging from studies regarding the benefits of between-country collaboration to local planning of marine protected areas) at different scales, using data from both field surveys and expert (and model based) estimations of species distributions.

\section{DISCUSSION}

\section{Marine protected areas}

Systematic conservation planning should be used for the establishment of new marine protected areas (MPAs). Based on the recent 2012 IUCN report, there are currently 161 MPAs in the Mediterranean Sea with a national designation, ranging in size between 0.01 and $4009 \mathrm{~km}^{2}$ (median of $24.3 \mathrm{~km}^{2}$; Gabrié et al. 2012). Given that $80 \%$ of the MPAs in the Mediterranean Sea are $<200 \mathrm{~km}^{2}$ in size, fine-spatial-resolution data is required for the proper management of most new MPAs, while broad-scale analyses (as in Mouillot et al. 2011, Coll et al. 2012, Portman et al. 2012, Levin et al. 2013, Mazor et al. 2013, Micheli et al. 2013a) may be suitable for the broad identification of candidate areas for MPA designation. As shallow areas (up to $100 \mathrm{~m}$ ) cover just $13.8 \%$ of the Mediterranean Sea, and as most (76\%) of the shallow areas are within regions claimed by Mediterranean countries (e.g. their territorial or internal seas), efforts can be directed to collect fine-spatial-resolution data of bathymetry, habitats, and species distribution within those shallow areas that are more accessible, and where pressures on biodiversity and species richness are often higher (Coll et al. 2010).

The management of marine resources, including MPAs, requires detailed knowledge of species and habitat distribution within the borders of the managed area. This information should be combined with spatial data on anthropogenic pressures such as fishing, shipping, and tourism (e.g. Giakoumi et al. 2011, 2012b, Coll et al. 2012, Micheli et al. 2013b, Parravicini et al. 2013). However, even the legal activities are presently subjected to a framework of regulations that do not completely acknowledge their potential impacts. They seldom co-exist without conflict, since the use of the marine environment for one purpose is often detrimental to another. At present, interactions between a suite of human pressures and the status of different ecosystem types has been quantified and visually represented in only a few MPAs (Parravicini et al. 2013). Once MPAs are in place, the agencies managing them often provide the funds for monitoring changes within them (as in Ramos-Esplá \& Valle Pérez 2004).

\section{Spatial marine information - availability, gaps, and challenges}

As we have shown in this review, spatial marine information covering the entire Mediterranean Sea is often incomplete (e.g. the EUSeaMap project for marine habitats covering only the Western Mediterranean) or of low spatial resolution (e.g. for about half of the Mediterranean, the best available bathymetric data is not from multibeam surveys but from global low-resolution datasets such as GEBCO). 
Table 1. The spatial resolution and data used in recent systematic conservation planning studies in the Mediterranean Sea

\begin{tabular}{|c|c|c|c|c|c|c|}
\hline Reference & Region studied & $\begin{array}{l}\text { Total } \\
\text { area } \\
\text { covered } \\
\left(\mathrm{km}^{2}\right)\end{array}$ & $\begin{array}{l}\text { Number } \\
\text { and } \\
\text { shape of } \\
\text { planning } \\
\text { units }\end{array}$ & $\begin{array}{l}\text { Planning } \\
\text { units } \\
\text { size } \\
\left(\mathrm{km}^{2}\right)\end{array}$ & $\begin{array}{l}\text { Planning } \\
\text { units size as } \\
\text { a ratio of the } \\
\text { total study } \\
\text { area }(\%)\end{array}$ & Biodiversity data used \\
\hline Fraschetti et al. (2009) & $\begin{array}{l}\text { Apulian coastline, } \\
\text { Italy }\end{array}$ & 26 & $\begin{array}{c}2603 \\
\text { squares }\end{array}$ & 0.01 & 0.038 & 13 habitat classes \\
\hline Maiorano et al. (2009) & $\begin{array}{l}\text { Ligurian and } \\
\text { Tyrrhenian coasts, Italy }\end{array}$ & 33600 & $\begin{array}{c}84 \\
\text { squares }\end{array}$ & 400 & 1.2 & $\begin{array}{l}\text { Abundance of fish, cephalopods } \\
\text { and crustacean species from } \\
\text { a trawl survey }\end{array}$ \\
\hline Giakoumi et al. (2011) & $\begin{array}{l}\text { Coastal waters (up to } \\
1 \mathrm{~km} \text { from shore) of } 26 \\
\text { islands in the Cyclades } \\
\text { Archipelago, Greece }\end{array}$ & 896 & $\begin{array}{c}224 \\
\text { squares }\end{array}$ & $\begin{array}{l}2 \text { to } 10 \\
\text { average } \\
\quad \text { of } 4\end{array}$ & 0.45 & $\begin{array}{l}\text { Three critical habitat types (the } \\
\text { seagrasses Posidonia oceanica } \\
\text { and Cymodocea nodosa and } \\
\text { forests of the macroalgae Cysto- } \\
\text { seira), abundance of fish species } \\
\text { and types of physical habitat }\end{array}$ \\
\hline Giakoumi et al. (2012b) & $\begin{array}{l}\text { The Greek Ionian Sea } \\
\text { and the adjacent gulfs } \\
\text { (Korinthiakos and } \\
\text { Patraikos gulfs) }\end{array}$ & 15331 & $\begin{array}{c}15331 \\
\text { squares }\end{array}$ & 1 & 0.007 & $\begin{array}{l}\text { Four high priority habitats, } \\
\text { and } 13 \text { lower priority habitats } \\
\text { and species }\end{array}$ \\
\hline Giakoumi et al. (2013) & $\begin{array}{l}\text { Mediterranean Sea, } \\
<1000 \text { m deep }\end{array}$ & 1321120 & $\begin{array}{c}13212, \\
\text { squares }\end{array}$ & 100 & 0.004 & $\begin{array}{l}\text { Seagrass Posidonia oceanica } \\
\text { meadows, coralligenous } \\
\text { formations, and partially or } \\
\text { totally submerged marine caves }\end{array}$ \\
\hline Giannoulaki et al. (2013) & $\begin{array}{l}\text { Entire } \\
\text { Mediterranean Sea }\end{array}$ & 2525000 & $\begin{array}{l}2860 \\
\text { hexagons }\end{array}$ & 1039 & 0.041 & $\begin{array}{l}\text { Seagrass Posidonia oceanica } \\
\text { meadows, coralligenous } \\
\text { formations }\end{array}$ \\
\hline Levin et al. (2013) & $\begin{array}{l}\text { Entire } \\
\text { Mediterranean Sea }\end{array}$ & 2525000 & $\begin{array}{l}26946 \\
\text { squares }\end{array}$ & 100 & 0.004 & $\begin{array}{l}77 \text { threatened species, IUCN } \\
\text { distribution range polygons }\end{array}$ \\
\hline Mazor et al. (2013) & $\begin{array}{l}\text { Entire } \\
\text { Mediterranean Sea }\end{array}$ & 2525000 & $\begin{array}{c}26946, \\
\text { squares }\end{array}$ & 100 & 0.004 & $\begin{array}{l}77 \text { threatened species, IUCN } \\
\text { distribution range polygons }\end{array}$ \\
\hline Mazor et al. (2014) & $\begin{array}{l}\text { Entire } \\
\text { Mediterranean Sea }\end{array}$ & 2525000 & $\begin{array}{c}26946 \\
\text { squares }\end{array}$ & 100 & 0.004 & $\begin{array}{l}77 \text { threatened species, IUCN } \\
\text { distribution range polygons }\end{array}$ \\
\hline
\end{tabular}

Despite the substantial gaps in our knowledge of species distribution, there is a very large amount of biodiversity information scattered all over the Mediterranean countries and different institutes. The knowledge needed to assess the distribution and status of many key species could be built by harmonizing and integrating information that has often been collected using different protocols and which is distributed in various repositories. With coordinated and targeted efforts, even in Mediterranean areas considered as data poor, spatial information on the most important biodiversity components may become available for conservation planning (Portman et al. 2013). One approach to increase the accessibility of biodiversity information is to create networks of online web services through which information in a variety of resources can be accessed (Gatto et al. 2013), as done in EurOBIS (Vandepitte et al. 2011).
With the increase in coordination between countries (especially within the EU), new collaborative databases are being developed and made available online, such as the EMODnet for bathymetric data, the EUSeaMap project for marine habitats, the EASIN for the spatial distribution alien marine species, as well as the Food and Agriculture Organization aquatic species distribution map server (www.fao. org/fishery/species/distribution). While it is becoming more common for researchers to publish datasets (including spatial GIS layers) through online archives (such as Pangaea, at www.pangaea.de; Diepenbroek et al. 2002), another option that is emerging is to publish the data through journals that provide archiving services, especially when the data itself is peerreviewed before publication (Costello \& Wieczorek 2014). In addition to these possibilities of data publication, it may be useful to establish an integrated 
archive for the Mediterranean Sea that will enable exploration of the metadata of marine datasets, including bathymetry, habitats, and biodiversity. Ongoing projects, such as the MEDISEH MAREA data viewer (http://mareaproject.net/medviewer/) have created and collated various data layers, including marine habitats, fish distribution, and model predictors, which will eventually become available (Giannoulaki et al. 2013). However, institutional efforts at the national and supranational level are still needed to move forward in this challenge.

Currently, the main knowledge gaps for marine habitats and species distribution are mostly in the eastern and southern regions of the Mediterranean Sea. The main data sources for the living resources in the Mediterranean Sea are regional competent organizations, such as the Barcelona Convention and relevant protocols, the General Fisheries Commission for the Mediterranean (GFCM), the European Environmental Agency (EEA), the Mediterranean Science Commission (CIESM), the International Commission for the Conservation of Atlantic Tunas (ICCAT), and the Agreement on the Conservation of Cetaceans in the Black Sea, Mediterranean Sea and Contiguous Atlantic Area (ACCOBAMS). The Mediterranean Ocean Biogeographic Information System (MedOBIS) is one of the online initiatives aiming at collecting, formatting, and disseminating marine biological data for the Eastern Mediterranean and Black seas (Arvanitidis et al. 2006). In addition, the European Union funded the $3 \mathrm{yr}$ Marine Ecosystems Dynamics and Indicators for North Africa (MEDINA) project enhancing the capacities of Northern African Countries (Morocco, Algeria, Tunisia, Libya, and Egypt) to monitor their Mediterranean coastal ecosystems (including fish stocks resources) using Earth observation systems (www.medinaproject.eu/puplic/ home.php).

At present, the best Mediterranean-wide map showing the type of bottom sediments is the Unconsolidated Bottom Surface Sediments of the Mediterranean and Black Seas, at a scale of 1:1000000 (Emelyanov et al. 1996). Harris et al. (2014) have recently published the first digital seafloor geomorphic features map of the global oceans, including 29 geomorphic feature categories (of which 23 categories are present in the Mediterranean Sea, e.g. seamounts, canyons, escarpments).

In the recent EUSeaMap, II/EModnet II kickoff meeting at the beginning of October 2013, it was proclaimed that they will aim to map the Eastern Mediterranean and Black seas with an (if possible) amended EUNIS classification (https://webgate.ec. europa.eu/maritimeforum/sites/maritimeforum/files/ modeg_habitats.pptx — accessed 14 July 2014). The EUNIS classification scheme was originally developed with data from Britain and Ireland by the Joint Nature Conservation Committee (JNCC) Marine Nature Conservation Review (MNCR) as part of the European Commission Life Nature-funded BioMar project (Connor et al. 1997a,b). Recent attempts to also better represent southern European countries are still in their infancy. The Mediterranean has certain distinct biological, ecological, and geomorphological features when compared with the North Atlantic marine systems (Narayanaswamy et al. 2013), which can be accommodated by updating the classification where needed, e.g. with regards to the Mediterranean deep-sea habitats. The Mediterranean scientific community is thus facing some difficulties in the application of EU standards (Galparsoro et al. 2012).

The existence of areas beyond territorial waters that have not been claimed as exclusive economic zones (EEZs) in the Mediterranean Sea requires a high level of cooperation among Mediterranean countries. Particularly, to ensure sustainable utilization of the marine living resources, mainly transboundary stocks, sedentary species, and highly migratory species. One of the significant obstacles for effective marine conservation planning of the Mediterranean Sea is the low level of cooperation between some of the Mediterranean countries (Levin et al. 2013). In addition, some of the Mediterranean countries (Israel, Libya, Syria, and Turkey) have not endorsed the UNCLOS, which is a regulatory convention for EEZs (the marine zone in which a country has special rights over the exploration and use of marine resources, including energy production from water and wind; the extent of an EEZ is from the country's coastline baseline out to a maximum of 200 nautical miles). Some of the countries are members of the European Union (EU) and follow the necessary regulations, such as the Marine Strategy Framework Directive, as the overarching framework for other directives (e.g. Birds and Habitat Directive). Other countries are not members and thus are not obliged to follow these regulations. There are also some legal barriers to EEZ delimitation and consequently overlapping claims for EEZ areas are not only common in the Eastern Mediterranean but also in the Western Mediterranean and the Adriatic region (Suárez de Vivero et al. 2010).

One of the prerequisites that may facilitate collaboration in marine conservation planning is the development of standards for mapping biodiversity 
features and bathymetry, as well as the availability of socioeconomic datasets (Ban \& Klein 2009, Ban et al. 2009). While generally there are no internationally accepted standards for mapping in terrestrial or marine ecosystems (Giri et al. 2005, Howell 2010), there is one notable case where such an international standard does exist: the International Hydrographic Organization Standards for Hydrographic Surveys (Special Publication 44 [SP-44]; IHO 2008, p. 1). As stated, the main aim of the SP-44 (first published in 1968) is 'determining the density and precision of measurements necessary to portray the sea bottom and other features sufficiently accurately for navigational purposes'. Four orders of survey are defined within SP-44, each designed to cater for a range of needs, their requirements decreasing with water depth and varying with expected shipping types (Table S2 in the Supplement at www.int-res.com/ articles/suppl/m508p261_supp.pdf).

Habitats can be geophysical, and/or biogenic, and the definition is scale dependent. Therefore, Costello (2009) recommended the use of separate classifications for (1) nekton, plankton, and benthos, and (2) regions, seascapes, biotopes, and guilds, as a function of the relevant scale and sampling methods used. Therefore, it may not be possible to define globally applicable standards for mapping habitats for the sake of marine conservation planning. Additional challenges hindering the formation of a single set of habitat classes are due to language-related difficulties, and the incoherence of some typologies used in EU classifications and directives (Dauvin et al. 2008a,b). One of the current efforts towards a revision of a habitat classification scheme for the development of a framework that is applicable throughout the region is being done as part of an EU funded project, known as CoCoNET (www.coconetfp7.eu/).

Information about bathymetry, marine habitats, or species distribution is often classified (thus nonaccessible) for national security purposes, commercial fishing interests, or for protection purposes. This jeopardizes conservation planning. While it is true that many protected areas have been declared in an opportunistic way without knowledge on their biodiversity, this has resulted in protected areas being biased towards locations with relatively low species richness (as analyzed by Joppa \& Pfaff 2009 for the USA). Furthermore, such areas fail in being representative of the full range of marine biodiversity features (as discussed by Barr \& Possingham 2013 for Australian MPAs). Using systematic conservation planning, one aims to achieve conservation targets for biodiversity features, thus acquisition of data on the spatial distribution of biodiversity features is critical to ensure features are represented within protected areas (Margules \& Pressey 2000).

Following the end of the cold war, past restrictions on the availability of remote-sensing data have eased (Williamson, 1997, Day et al. 1998), and this may also be the case with bathymetric information in the future. However, the present situation may also have some advantages, as the location of some areas where endangered and over-exploited species (or habitats) may still be flourishing remains unknown, at least partly, to the fishing industry. Nonetheless, when distribution maps of endangered species or critical habitats are classified, these species or habitats might be impacted by other threats such as undersea cables and infrastructure planned in these areas, as they were not known to be sensitive or worth preserving. As citizen science becomes an ever increasingly important source of spatial information in terrestrial areas (Goodchild 2007), there may also be a role for it in marine ecosystems (Delaney et al. 2008), at least for shallow areas. Examples of marine citizen science in the Mediterranean include the Jellywatch Program, a citizen science initiative launched in the summer of 2009 by CIESM (www.ciesm.org/marine/programs/jellywatch.htm; Boero et al. 2009), and the Citizen's Network for the Observation of Marine BiodivERsity (COMBER; www.comber.hcmr.gr/?q=content/home, Arvanitidis et al. 2011), a pilot project taking place in Greece, as part of the Virtual Biodiversity Research and Access Network for Taxonomy (ViBRANT) EU FP7 project.

In practice, when detailed information about the spatial distribution of species is lacking, bathymetry, environmental data, and marine geomorphology can be used as proxies for marine habitats (Wright \& Heyman 2008, Heyman \& Wright 2011). While freely available online species distribution maps provided by international organizations such as IUCN can be useful in revealing global spatial patterns, when planning at more detailed scales (local, national, or regional) these global data should be regarded with caution, and other spatial data sources (e.g. raw data points from OBIS datasets) may be more useful if available. The example of the seagrass discussed earlier provides evidence that relying on the IUCN dataset could misinform conservation planning. As mentioned above, there are at present multiple regional efforts to increase the availability, and to create finer-detailed maps, of marine habitats and of fish habitats (Druon et al. 2011, Giakoumi et al. 2013, Giannoulaki et al. 2013). 
While spatial information for detailed marine conservation planning in the Mediterranean Sea is lacking, based on various proposed conservation initiatives, about 10 areas, encompassing ca. $10 \%$ of the Mediterranean Sea, were overlapping and consistently suggested as priority areas for conservation (often without using systematic conservation planning principles; Micheli et al. 2013a). Constraining such areas by the costs that are required to preserve them (Mazor et al. 2014) has refined these overlapping priority areas to $\sim 2.5 \%$ as a potential starting point for determining spatial priorities in the basin. We therefore recommend that increased research and funding efforts should be allocated to the biologically significant areas in the Mediterranean Sea to fill the scientific gaps. This should include data collection and using online publishing of datasets, which may be accomplished through existing initiatives such as GBIF (www.gbif.org), OBIS (www.iobis. org), the World Register of Marine Species (WoRMS; Appeltans et al. 2011), and the PANGAEA Data Publisher for Earth and Environmental Science (www. pangaea.de). Providing free access to data for marine spatial planning will enhance our ability for the systematic planning, declaration, and management of new marine protected areas in the Mediterranean Sea (Coll et al. 2013, and as recommended in the recent Proposal for a Directive of the European Parliament and of The Council, 'Establishing a framework for maritime spatial planning and integrated coastal management'; available at http://eur-lex. europa.eu/LexUriServ/LexUriServ.do?uri=COM:201 3:0133:FIN:EN:PDF — accessed 2 December 2013). If funding agencies will state that scientists are required to make their datasets available online (once they have been scientifically published), the rate of online publishing of datasets may be increased. At the same time, the inclusion of socioeconomic data in conservation planning is necessary as the conservation priorities can be significantly modified when human activities and opportunity cost for those are explicitly taken into account (Mazor et al. 2014). Two of the EU initiatives in this field are the PEGASO project, aimed at constructing a shared Integrated Coastal Zone Management (ICZM) Governance Platform with scientists, users, and decision-makers linked with new models of governance (www.pegaso project.eu/), and the Policy-oriented marine Environmental Research for the Southern European Seas (PERSEUS) project, that merges natural and socioeconomic sciences to predict the long-term effects of these pressures on marine ecosystems (www. perseus-net.eu/site/content.php).
In our view, the lack of data accessibility and dataquality information is a more significant bottleneck to Mediterranean conservation efforts than a lack of data inter-compatibility, standardization, and differences in completeness and resolution. Long-running efforts to standardize metadata formats of spatial data for automated data exchange and processing by the environmental sciences (Michener et al. 1997, Jones et al. 2001, Lemmens \& de By 2002, Tsou 2002) have recently yielded a plethora of application-specific standards without any clear winners (Rose 2012, Costello et al. 2013). With data standardization and automated processing being an elusive concept 3 decades on, a consensus is emerging that the ability to process data depends largely on the quality and completeness of its source, described in a perhaps non-standard manner, rather than adherence to standardized metadata descriptions for intended uses within a specific scientific field (Rose 2012). In addition, patchy and sparse data are not necessarily rendered unsuitable for conservation purposes; complementary datasets at different resolutions may enhance understanding of an area's characteristics when used in unison.

\section{Recommendations}

We propose a roadmap to a peer-reviewed datasharing system for conservation purposes (in the Mediterranean and elsewhere), which encompasses: - Establishment of a central 'repository of data sources' for conservation efforts, where available datasets of different natures, their characteristics, resolution, or scale and quality are listed. At present, there are permanent professional archives including data covering a variety of thematic resources (e.g. www.iucn.org, www.mediterranean-marinedata.eu, http://imdis2013.seadatanet.org, www.mamias.org, www.ciesm.org/online/atlas/intro.htm). There are also EU projects such as CoCoNET, including a WebGIS system that will provide access to and integration of all types of data and information produced by the project. A centralized Geodatabase and a WebGIS system will be the linking tool for all CoCoNET partners, regions, and thematic research. It will involve the entire consortium at different levels in topics such as data provision, GIS products, GIS interpretation, data archiving, and data exchange. At the end of the CoCoNET project, it will feed Seadatanet, which is another professional permanent archive. A similar tool was developed also by other projects such as MEDISEH MAREA. However, there 
is a general reluctance to release datasets under an 'open access' license and the potential to combine all the available information under a common 'umbrella' is yet to be achieved.

- Reinforcement of initiatives at the European level (such as EMODnet Biology) to provide access to currently inaccessible datasets on depth, habitats, and species distribution. This is especially important to make data accessible from the southeastern regions or databases currently not freely available due to access restrictions, e.g. data from the European Data Framework Collection.

- Design of efforts to harmonize current approaches in marine mapping and to develop a framework applicable throughout the Mediterranean region before more countries undertake further extensive habitat mapping, so that future conservation planning can use integrated spatial datasets that are also gathered for other disciplines, e.g. from marine surveys, natural resource explorations, construction projects, cruise operations.

- Increase in collaborative research effort, funding allocation, data collection, and free access to data. These should target the biologically significant areas in the Mediterranean Sea as well as areas where knowledge on the system is currently too scarce to even determine their possible importance (i.e. southern and southeastern regions). These efforts should fill the scientific gaps and improve marine spatial planning, which will facilitate the planning, declaration, and management of new marine protected areas in the Mediterranean Sea.

- High priority given to surveying both shallow near-coastal areas (that are exposed to anthropogenic threats) as well as deep-sea areas. Although some information concerning the deep Mediterranean has been collected, especially through national projects, systematic efforts should be directed to mapping special features, such as seamounts and canyons.

Acknowledgements. The data shown in Fig. 1d,e is derived from the Israel National Bathymetric Mapping Project, conducted by the Israel Oceanographic and Limnological Research and the Geological Survey of Israel. The map shown in Fig. 1g was extracted from Sade et al. (2006b), courtesy of Ronnie Sade and John Hall. M.C. was funded by the Marie Curie Career EU Integration Grant Fellowships to the BIOWEB project and by the Spanish National Program Ramon y Cajal. S.F. was supported by the project CoCoNET funded by the EU. S.G. was supported by the project NETMED co-funded by the European Social Fund and the Greek State. G.R. was funded by the Marie Curie Career EU Reintegration Grant and the EU 7th Framework Programme for the project Vectors of Change in Oceans and Seas Mar- ine Life, Impact on Economic Sectors (VECTORS). J.J.H thanks MASTS for funding. We thank all participants of the 2nd International Workshop 'Advancing Conservation Planning in the Mediterranean Sea' (8-11 April 2013; Nahsholim, Israel) for discussions and contributions that inspired and shaped this paper. T.M. received funding from CEED to attend the 2013 workshop in Israel.

\section{LITERATURE CITED}

Albouy C, Velez L, Coll M, Colloca F, Le Loc'h F, Mouillot D, Gravel D (2014) From projected species distribution to food-web structure under climate change. Glob Change Biol 20:730-741

Allott P (1983) Power sharing in the law of the sea. Am J Int Law 77:1-30

Amante C, Eakins BW (2009) ETOPO1 1 arc-minute global relief model: procedures, data sources and analysis. Technical Memorandum NESDIS NGDC-24, NOAA, Washington, DC

Andelman SJ, Fagan WF (2000) Umbrellas and flagships: efficient conservation surrogates or expensive mistakes? Proc Natl Acad Sci USA 97:5954-5959

Anderson JT, Van Holliday D, Kloser R, Reid DG, Simard Y (2008) Acoustic seabed classification: current practice and future directions. ICES J Mar Sci 65:1004-1011

Appeltans W, Bouchet P, Boxshall GA, Fauchald K and others (eds) (2011) World register of marine species (WoRMS). www.marinespecies.org

Ardron JA, Possingham HP, Klein CJ (eds) (2008) Marxan good practices handbook. University of Queensland, Brisbane

Arvanitidis C, Valavanis VD, Eleftheriou A, Costello MJ and others (2006) MedOBIS: biogeographic information system for the eastern Mediterranean and Black Sea. Mar Ecol Prog Ser 316:225-230

Arvanitidis C, Faulwetter S, Chatzigeorgiou G, Penev L and others (2011). Engaging the broader community in biodiversity research: the concept of the COMBER pilot project for divers in ViBRANT. ZooKeys 150:211-229

- Ban NC, Klein CJ (2009) Spatial socioeconomic data as a cost in systematic marine conservation planning. Conserv Lett 2:206-215

Ban NC, Hansen GJ, Jones M, Vincent AC (2009) Systematic marine conservation planning in data-poor regions: socioeconomic data is essential. Mar Policy 33:794-800

> Barr LM, Possingham HP (2013) Are outcomes matching policy commitments in Australian marine conservation planning? Mar Policy 42:39-48

Beaman RJ (2010) Project 3DGBR: a high-resolution depth model for the Great Barrier Reef and Coral Sea. Marine and Tropical Sciences Research Facility (MTSRF) Project 2.5i.1a Final Report, Reef and Rainforest Research Centre, Cairns

- Ben Rais Lasram F, Guilhaumon F, Mouillot D (2009) Fish diversity patterns in the Mediterranean Sea: deviations from a mid-domain model. Mar Ecol Prog Ser 376:253-267

Ben Rais Lasram F, Guilhaumon F, Somot S, Thuiller W, Mouillot D (2010) The Mediterranean Sea as a 'cul-desac' for endemic fishes facing climate change. Glob Change Biol 16:3233-3245

> Bertrand JA, Gil de Sola L, Papaconstantinou C, Relini G, Souplet A (2002) The general specifications of the MEDITS surveys. Sci Mar 66(Suppl 2):9-17 
Boero F, Putti M, Trainito E, Prontera E, Piraino S, Shiganova TA (2009) First records of Mnemiopsis leidyi (Ctenophora) from the Ligurian, Thyrrhenian and Ionian Seas (Western Mediterranean) and first record of Phyllorhiza punctata (Cnidaria) from the Western Mediterranean. Aquatic Invasions 4:675-680

Bosc E, Bricaud A, Antoine D (2004) Seasonal and interannual variability in algal biomass and primary production in the Mediterranean Sea, as derived from 4 years of SeaWiFS observations. Global Biogeochem Cycles 18:GB1005, doi:10.1029/2003GB002034

Brown CJ, Blondel P (2009) Developments in the application of multibeam sonar backscatter for seafloor habitat mapping. Appl Acoust 70:1242-1247

> Carr MH, Neigel JE, Estes JA, Andelman S, Warner RR, Largier JL (2003) Comparing marine and terrestrial ecosystems: implications for the design of coastal marine reserves. Ecol Appl 13(Suppl):90-107

Cheung WW, Lam VW, Sarmiento JL, Kearney K, Watson R, Pauly D (2009) Projecting global marine biodiversity impacts under climate change scenarios. Fish Fish 10:235-251

Chevalier C (2005) Governance of the Mediterranean Sea: outlook for the legal regime. IUCN-Med, Málaga

Christensen V, Walters CJ (2011) Progress in the use of ecosystem models for fisheries management. In: Christensen V, Maclean J (eds) Ecosystem approaches to fisheries: a global perspective. Cambridge University Press, Cambridge, $p$ 189-205

Chust G, Grande M, Galparsoro I, Uriarte A, Borja Á (2010) Capabilities of the bathymetric Hawk Eye LiDAR for coastal habitat mapping: a case study within a Basque estuary. Estuar Coast Shelf Sci 89:200-213

Coggan R, Populus J, White J, Sheehan K, Fitzpatrick F, Piel $\mathrm{S}$ (eds) (2007) Review of standards and protocols for seabed habitat mapping MESH, available at www.search mesh.net/Files/Standards_\&_Protocols_2nd\%20Edition.zip (accessed June 17, 2013)

Coll M, Piroddi C, Steenbeek J, Kaschner K and others (2010) The biodiversity of the Mediterranean Sea: estimates patterns and threats. PLoS ONE 5:e11842

Coll M, Piroddi C, Albouy C, Ben Rais Lasram F and others (2012) The Mediterranean Sea under siege: spatial overlap between marine biodiversity cumulative threats and marine reserves. Glob Ecol Biogeogr 21:465-480

Coll M, Cury P, Azzurro E, Bariche M and others (2013) The scientific strategy needed to promote a regional ecosystem-based approach to fisheries in the Mediterranean and Black seas. Rev Fish Biol Fish 23:415-434

Connor DW, Brazier DP, Hill TO, Northen KO (1997a) Marine nature conservation review: marine biotope classification for Britain and Ireland, Vol 1. Littoral biotopes. Version 97.06. Report No. 229, Joint Nature Conservation Committee, Peterborough

Connor DW, Dalkin MJ, Hill TO, Holt RHF, Sanderson WG (1997b) Marine nature conservation review: marine biotope classification for Britain and Ireland, Vol 2. Sublittoral biotopes. Version 97.06. Report No. 230, Joint Nature Conservation Committee, Peterborough

> Costello MJ (2009) Distinguishing marine habitat classification concepts for ecological data management. Mar Ecol Prog Ser 397:253-268

Costello MJ, Wieczorek J (2014) Best practice for biodiversity data management and publication. Biol Conserv 173:68-73
Costello MJ, Cheung A, De Hauwere N (2010a) Surface area and the seabed area volume depth slope and topographic variation for the world's seas oceans and countries. Environ Sci Technol 44:8821-8828

> Costello MJ, Coll M, Danovaro R, Halpin P, Ojaveer H, Miloslavich P (2010b) A census of marine biodiversity knowledge, resources, and future challenges. PLoS ONE 5:e12110

> Costello MJ, Michener WK, Gahegan M, Zhang ZQ, Bourne PE (2013) Biodiversity data should be published cited and peer reviewed. Trends Ecol Evol 28:454-461

- Danovaro R, Company BJ, Corinaldesi C, D'Onghia G and others (2010) Deep-sea biodiversity in the Mediterranean Sea: the known the unknown and the unknowable. PLoS ONE 5:e11832

Dauvin J, Bellan G, Bellan-Santini D (2008a) The need for clear and comparable terminology in benthic ecology. Part I. Ecological concepts. Aquatic Conserv 18:432-445

Dauvin JC, Bellan G, Bellan-Santini D (2008b) The need for clear and comparable terminology in benthic ecology. Part II. Application of the European Directives. Aquatic Conserv 18:446-456

Day DA, Logsdon JM, Latell B (eds) (1998) Eye in the sky: the story of the CORONA spy satellites. Smithsonian Institute Press, Washington, DC

Dekker AG, Phinn SR, Anstee J, Bissett P and others (2011) Intercomparison of shallow water bathymetry, hydrooptics, and benthos mapping techniques in Australian and Caribbean coastal environments. Limnol Oceanogr Methods 9:396-425

Delaney DG, Sperling CD, Adams CS, Leung B (2008) Marine invasive species: validation of citizen science and implications for national monitoring networks. Biol Invas 10:117-128

Diepenbroek M, Grobe H, Reinke M, Schindler U, Schlitzer R, Sieger R, Wefer G (2002) PANGAEA — an information system for environmental sciences. Comput Geosci 28:1201-1210

Douvere F (2010) Marine spatial planning: concepts, current practice and linkages to other management approaches. PhD thesis, Ghent University, Ghent

> Druon JN, Fromentin JM, Aulanier F, Heikkonen J (2011) Potential feeding and spawning habitats of Atlantic bluefin tuna in the Mediterranean Sea. Mar Ecol Prog Ser 439:223-240

> Druon JN, Panigada S, David L, Gannier A and others (2012) Potential feeding habitat of fin whales in the western Mediterranean Sea: an environmental niche model. Mar Ecol Prog Ser 464:289-306

> Duffy JE, Amaral-Zettler LA, Fautin DG, Paulay G, Rynearson TA, Sosik HM, Stachowicz JJ (2013) Envisioning a marine biodiversity observation network. BioScience 63:350-361

EC (European Commission) (2008) Directive of the European Parliament and the Council establishing a framework for community action in the field of marine environmental policy (Marine Strategy Framework Directive). European Commission Directive 2008/56/EC OJL 164. Available at http://eur-lex.europa.eu/legal-content/EN/ TXT/PDF/?uri=CELEX:32008L0056\&from=en

EC (European Commission) (2012) Guidance for 2012 reporting under the Marine Strategy Framework Directive using the MSFD database tool Version 1.0. DG Environment, Brussels

Emelyanov EM, Shimkus KM, Kuprin PN (1996) Unconsoli- 
dated bottom surface sediments of the Mediterranean and Black Seas. Intergovernmental Oceanographic Commission (UNESCO). IBCM Geol Geoph Series. Scale $1: 1,000,000$. St. Petersburg. Available at www.ngdc. noaa.gov/mgg/ibcm/ibcmbath.html (accessed July 15, 2014)

EU (European Union) (2011) Relationship between the initial assessment of marine waters and the criteria for good environmental status. Commission staff working paper SEC (2011) 1255 final. Available at http://ec.europa.eu/ environment/marine/pdf/SEC_2011_1255_F_DTS.pdf (accessed July 15, 2014)

FAO (Food and Agriculture Organization) (2012) Fishing vessel execution of acoustic surveys of deep-sea species: main issues and way forward. Circular No 1059, FAO Fisheries and Aquaculture, Rome

Fisher PF, Tate NJ (2006) Causes and consequences of error in digital elevation models. Prog Phys Geogr 30:467-489

Foster-Smith R, Connor D, Davies J (2007) What is habitat mapping? In: MESH guide to habitat mapping MESH Project 2007. Joint Nature Conservation Committee, Peterborough. Available at www.searchmesh.net/ default.aspx?page=1900 (accessed June 28, 2013)

Fouzai N, Coll M, Palomera I, Santojanni A, Arneri E, Christensen V (2012) Fishing management scenarios to rebuild exploited resources and ecosystems of the Northern-Central Adriatic (Mediterranean Sea). J Mar Syst 102-104:39-51

Fraschetti S, Terlizzi A, Boero F (2008) How many habitats are there in the sea (and where)? J Exp Mar Biol Ecol 366:109-115

Fraschetti S, D'Ambrosio P, Micheli F, Pizzolante F, Bussotti S, Terlizzi A (2009) Design of marine protected areas in a human-dominated seascape. Mar Ecol Prog Ser 375: 13-24

Fraschetti S, Guarnieri G, Bevilacqua S, Terlizzi A, Claudet J, Russo GF, Boero F (2011) Conservation of Mediterranean habitats and biodiversity countdowns: What information do we really need? Aquatic Conserv 21:299-306

Froese R, Pauly D (eds) (2013) FishBase. www.fishbase.org (accessed April 2013)

Gabrié C, Lagabrielle E, Bissery C, Crochelet E and others (2012) The status of marine protected areas in the Mediterranean Sea. MedPAN CAR/ASP Ed: MedPAN Collection. Available at www.medpan.org/documents/10180/0/ The+Status+of+the+Marine+Protected+Areas+in+the+ Mediterranean+Sea+2012/069bb5c4-ce3f-4046-82cf-f72 dbae29328

Galparsoro I, Connor DW, Borja A, Aish A and others (2012) Using EUNIS habitat classification for benthic mapping in European seas: present concerns and future needs. Mar Pollut Bull 64:2630-2638

> Gatto F, Katsanevakis S, Vandekerkhove J, Zenetos A, Cardoso AC (2013) Evaluation of online information sources on alien species in Europe - the need of harmonization and integration. Environ Manag 51:1137-1146

Giakoumi S, Grantham HS, Kokkoris GD, Possingham HP (2011) Designing a network of marine reserves in the Mediterranean Sea with limited socio-economic data. Biol Conserv 144:753-763

> Giakoumi S, Mazor T, Fraschetti S, Kark S and others (2012a) Advancing marine conservation planning in the Mediterranean Sea. Rev Fish Biol Fish 22:943-949

Giakoumi S, Katsanevakis S, Vassilopoulou V, Panayotidis P and others (2012b) Could European marine conservation policy benefit from systematic conservation planning? Aquatic Conserv 22:762-775

> Giakoumi S, Sini M, Gerovasileiou V, Mazor T and others (2013) Ecoregion-based conservation planning in the Mediterranean: dealing with large-scale heterogeneity. PLoS ONE 8:e76449

Giannoulaki M, Belluscio A, Panayotidis P, Fraschetti S and others (2013) Mediterranean sensitive habitats. DG MARE Specific Contract SI2.600741 Final Report. Hellenic Centre for Marine Research, Heraklion

Giri C, Zhu Z, Reed B (2005) A comparative analysis of the Global Land Cover 2000 and MODIS land cover data sets. Remote Sens Environ 94:123-132

Goodchild MF (2007) Citizens as sensors: the world of volunteered geography. GeoJournal 69:211-221

Hall JK (2008) The 25 meters DTM (digital terrain model) of Israel. Isr J Earth Sci 57:145-147

Halpern BS, Walbridge S, Selkoe KA, Kappel CV and others (2008) A global map of human impact on marine ecosystems. Science 319:948-952 .

Harris PT, Macmillan-Lawler M, Rupp J, Baker EK (2014) Geomorphology of the oceans. Mar Geol 352:4-24

> Heyman WD, Wright DJ (2011) Marine geomorphology in the design of marine reserve networks. Prof Geogr 63:429-442

Hinz H, Murray LG, Lambert GI, Hiddink JG, Kaiser MJ (2013) Confidentiality over fishing effort data threatens science and management progress. Fish Fish 14:110-117

Howell KL (2010) A benthic classification system to aid in the implementation of marine protected area networks in the deep/high seas of the NE Atlantic. Biol Conserv 143:1041-1056

IHO (International Hydrographic Organization) (2008) Standards for hydrographic surveys, 5th edn. Spec Publication 44, International Hydrographic Bureau, Monaco

IUCN (International Union for Conservation of Nature) (2012) IUCN red list of threatened species. Version 2012.1. www.iucnredlist.org (accessed 11 May 2013)

Johnson AF, Jenkins SR, Hiddink JG, Hinz H (2013) Linking temperate demersal fish species to habitat: scales, patterns and future directions. Fish Fish 14:256-280

Jones MB, Berkley C, Bojilova J, Schildhauer M (2001) Managing scientific metadata. IEEE Internet Comput 5:59-68

Jones MC, Dye SR, Pinnegar JK, Warren R, Cheung WW (2012) Modelling commercial fish distributions: prediction and assessment using different approaches. Ecol Modell 225:133-145

> Joppa LN, Pfaff A (2009) High and far: biases in the location of protected areas. PLoS ONE 4:e8273 .

Kaschner K, Ready JS, Agbayani E, Rius J and others (2010) AquaMaps: predicted range maps for aquatic species. Version 10/2009. www.aquamaps.org (accessed July 23, 2013)

Katsanevakis S, Maravelias CD (2009) Bathymetric distribution of demersal fish in the Aegean and Ionian Seas based on generalized additive modeling. Fish Sci 75: 13-23

Katsanevakis S, Bogucarskis K, Gatto F, Vandekerkhove J, Deriu I, Cardoso AC (2012) Building the European Alien Species Information Network (EASIN): a novel approach for the exploration of distributed alien species data. BioInvasions Records 1:235-245

- Katsanevakis S, Gatto F, Zenetos A, Cardoso AC (2013) How many marine aliens in Europe? Manage Biol Inv 4:37-42 Lemmens RLG, de By RA (2002) Distributed GIS and meta- 
data: methods for the description of interoperable GIS components. In: International Workshop on Mobile and Internet GIS. Wuhan, China, Aug 15-16, 2002. ISPRS Commission II Symposium, Working Group 5

> Leslie HM (2005) A synthesis of marine conservation planning approaches. Conserv Biol 19:1701-1713

> Levin N, Tulloch AIT, Gordon A, Mazor T, Bunnefeld T, Kark S (2013) Incorporating socio-economic and political drivers of international collaboration into marine conservation planning. BioScience 63:547-563

Ma S, Tao Z, Yang X, Yu Y, Zhou X, Li Z (2014) Bathymetry retrieval from hyperspectral remote sensing data in optical-shallow water. IEEE Trans Geosci Remote Sens 52: 1205-1212

> Maiorano L, Bartolino V, Colloca F, Abella A and others (2009) Systematic conservation planning in the Mediterranean: a flexible tool for the identification of no-take marine protected areas. ICES J Mar Sci 66:137-146

Margules CR, Pressey RL (2000) Systematic conservation planning. Nature 405:243-253

Margules CR, Pressey RL, Williams PH (2002) Representing biodiversity: data and procedures for identifying priority areas for conservation. J Biosci 27:309-326

- Marks KM, Smith WHF (2006) An evaluation of publicly available global bathymetry grids. Mar Geophys Res $27: 19-34$

Martin CS, Giannoulaki M, De Leo F, Scardi M and others (2014) Coralligenous and maërl habitats: predictive modelling to identify their spatial distributions across the Mediterranean Sea. Sci Rep 4, 5073, doi:10.1038/srep 05073

> Mazor T, Possingham HP, Kark S (2013) Collaboration among countries in marine conservation can achieve substantial efficiencies. Divers Distrib 19:1380-1393

Mazor T, Giakoumi S, Kark S, Possingham HP (2014) Largescale conservation planning in a multinational marine environment: cost matters. Ecol Appl 24:1115-1130

MEDIAS (2010) Report of 3rd meeting for MEDiterranean Acoustic Surveys (MEDIAS) in the framework of European Data Collection Framework. MEDIAS, Capo Granitola

Micheli F, Levin N, Giakoumi S, Katsanevakis S and others (2013a) Setting priorities for regional conservation planning in the Mediterranean Sea. PLoS ONE 8:e59038

Micheli F, Halpern BS, Walbridge S, Ciriaco S and others (2013b) Cumulative human impacts on Mediterranean and Black Sea marine ecosystems: assessing current pressures and opportunities in seas under siege. PLoS ONE 8:e79889

Michener WK, Brunt JW, Helly JJ, Kirchner TB, Stafford SG (1997) Non geospatial metadata for the ecological sciences. Ecol Appl 7:330-342

Moilanen A, Wilson KA, Possingham HP (2009) Spatial conservation prioritization: quantitative methods computational tools. Oxford University Press, Oxford

> Morfin M, Fromentin JM, Jadaud A, Bez N (2012) Spatiotemporal patterns of key exploited marine species in the northwestern Mediterranean Sea. PLoS ONE 7:e37907

Mouillot D, Albouy C, Guilhaumon F, Ben Rais Lasram F and others (2011) Protected and threatened components of fish biodiversity in the Mediterranean Sea. Curr Biol 21:1044-1050

Mumby PJ, Skirving W, Strong AE, Hardy JT and others (2004) Remote sensing of coral reefs and their physical environment. Mar Pollut Bull 48:219-228
Narayanaswamy BE, Coll M, Danovaro R, Davidson K, Ojaveer H, Renaud P (2013) Synthesis of knowledge on marine biodiversity in European Seas: from census to sustainable management. PLoS ONE 8:e58909

OSPAR (2003) Initial OSPAR list of threatened and/or declining species and habitats. Biodiversity Series, OSPAR Commission, London

> Pandian PK, Ruscoe JP, Shields M, Side JC, Harris RE, Kerr SA, Bullen CR (2009) Seabed habitat mapping techniques: an overview of the performance of various systems. Mediterranean Mar Sci 10:29-44

> Parravicini V, Micheli F, Montefalcone M, Morri C and others (2013) Conserving biodiversity in a human-dominated world: degradation of marine sessile communities within a protected area with conflicting human uses. PLoS ONE 8:e75767

Pergent G, Bazairi $\mathrm{H}$, Bianchi $\mathrm{CN}$, Boudouresque $\mathrm{CF}$ and others (2012) Mediterranean seagrass meadows: resilience and contribution to climate change mitigation: a short summary. IUCN, Gland/Málaga

Portman ME, Nathan D, Levin N (2012) From the Levant to Gibraltar: a regional perspective for marine conservation in the Mediterranean Sea. Ambio 41:670-681

Portman ME, Notarbartolo di Sciara G, Agardy T, Katsanevakis S, Possingham H, di Carlo G (2013) He who hesitates is lost: Why conserving the Mediterranean is both necessary and possible now. Mar Policy 42:270-279

Ramos-Esplá AA, Valle Pérez C (2004) Regional project for the development of marine and coastal protected areas in the Mediterranean region (MedMPA). Final report (Activity MP4): marine biodiversity study of the Rosh Haniqra-Akhziv nature reserves (Israel) to the establishment of a management plan. United Nations Environmental Program, Alicante. Available at http://medmpa. rac-spa.org/pdf/Rapports/Israel/Rapport.pdf

Rose KA (2012) End-to-end models for marine ecosystems: Are we on the precipice of a significant advance or just putting lipstick on a pig? Sci Mar 76:195-201

Rovere A, Ferraris F, Parravicini V, Navone A, Morri C, Bianchi CN (2013) Characterization and evaluation of a marine protected area: 'Tavolara-Punta Coda Cavallo' (Sardinia, NW Mediterranean). J Maps 9:279-288

Sade AR, Hall JK, Amit G, Golan A, Gur-Arieh L, Tibor G (2006a) The Israel national bathymetric survey - a new look at the seafloor off Israel. Isr J Earth Sci 55:185-187

Sade AR, Hall JK, Golan A, Amit G and others (2006b) High resolution bathymetry of the Mediterranean Sea off northern Israel. Poster, GSI Report GSI/20/2006 and IOLR Report H44/2006. Available at http://searchworks. stanford.edu/view/8359971

Salomidi M, Katsanevakis S, Borja Á, Braeckman U and others (2012) Assessment of goods and services vulnerability and conservation status of European seabed biotopes: a stepping stone towards ecosystem-based marine spatial management. Mediterranean Mar Sci 13:49-88

Schaap D, Moussat E (2013) EMODNet HydrographySeabed Mapping - Developing a higher resolution digital bathymetry for the European seas. In: EGU General Assembly Conference Abstracts, Vol 15. European Geosciences Union, Vienna, p 3620

Simon C, Vandepitte L, Waumans F, Vanhoorne B, Hernandez F (2013) EurOBIS as biogeographic data system for the European Marine Observation and Data Network (EMODnet). In: Mees J, Seys J (eds) Book of abstracts VLIZ Young Scientists' Day. Brug, Belgium, 15 February 
2013. VLIZ Special Publication 63. Vlaams Instituut voor de Zee (VLIZ), Oostende, p 25. Available at www.vliz.be/ imisdocs/publications/242993.pdf

Spalding MD, Fox HE, Allen GR, Davidson N and others (2007) Marine ecoregions of the world: a bioregionalization of coastal and shelf areas. BioScience 57:573-583

Steenbeek J, Coll M, Gurney L, Melin F, Hoepffner N, Buszowski J, Christensen V (2013) Bridging the gap between ecosystem modeling tools and geographic information systems: driving a food web model with external spatial-temporal data. Ecol Modell 263:139-151

Stevens T, Connolly RM (2004) Testing the utility of abiotic surrogates for marine habitat mapping at scales relevant to management. Biol Conserv 119:351-362

Stumpf RP, Holderied K, Sinclair M (2003) Determination of water depth with high-resolution satellite imagery over variable bottom types. Limnol Oceanogr 48:547-556

Suárez de Vivero JL, Rodríguez Mateos JC, Florido del Corral D (2009) Geopolitical factors of maritime policies and marine spatial planning: state regions and geographical planning scope. Mar Policy 33:624-634

Suárez de Vivero JL, Martínez Alba I, Martín Jiménez JM, Jiménez Sánchez C (2010) Jurisdictional waters in the Mediterranean and Black seas. Directorate-General for Internal Policies, Policy Department B: Structural and Cohesion Policies, Fisheries, IP/B/PECH/IC/2009-087 PE 431.602, European Parliament, Brussels. Available at www.eurocean.org/np4/file/2063/download.do.pdf

Tecchio S, Ramírez-Llodra E, Sardà F (2010) Biodiversity of deep-sea demersal megafauna in western and central Mediterranean basins. Sci Mar 75:341-350

Tsou MH (2002) An operational metadata framework for searching indexing and retrieving distributed geographic

Editorial responsibility: Lisandro Benedetti-Cecchi, Pisa, Italy information services on the internet. In: Egenhofer MJ, Mark DM (eds) Geographic information science. Lecture notes in computer science, Vol 2478. Springer, Berlin, p 313-332

Turra A, Cróquer A, Carranza A, Mansilla A and others (2013) Global environmental changes: setting priorities for Latin American coastal habitats. Glob Change Biol 19:1965-1969

> Vandepitte L, Hernandez F, Claus S, Vanhoorne B and others (2011) Analysing the content of the European Ocean Biogeographic Information System (EurOBIS): available data, limitations, prospects and a look at the future. Hydrobiologia 667:1-14

> Villa F, Tunesi L, Agardy T (2002) Zoning marine protected areas through spatial multiple-criteria analysis: the case of the Asinara Island National Marine Reserve of Italy. Conserv Biol 16:515-526

> Ward TJ, Vanderklift MA, Nicholls AO, Kenchington RA (1999) Selecting marine reserves using habitats and species assemblages as surrogates for biological diversity. Ecol Appl 9:691-698

Williamson RA (1997) The Landsat legacy: remote sensing policy and the development of commercial remote sensing. Photogramm Eng Remote Sensing 63:877-885

> Wozencraft J, Millar D (2005) Airborne lidar and integrated technologies for coastal mapping and nautical charting. Mar Technol Soc J 39:27-35

> Wright DJ, Heyman WD (2008) Introduction to the special issue: marine and coastal GIS for geomorphology habitat mapping and marine reserves. Mar Geod 31:223-230

Zacharias MA, Roff JC (2001) Use of focal species in marine conservation and management: a review and critique. Aquatic Conserv 11:59-76

Submitted: December 3, 2013; Accepted: May 9, 2014 Proofs received from author(s): July 16, 2014 